\title{
Simulation of Heavy Lake-Effect Snowstorms across the Great Lakes Basin by RegCM4: Synoptic Climatology and Variability*,+
}

\author{
Michael NotARo \\ Nelson Center for Climatic Research, University of Wisconsin-Madison, Madison, Wisconsin \\ AZAR ZARRIN \\ Department of Geography, Ferdowsi University of Mashhad, Mashhad, Iran \\ STEVE VAVRUS AND VAL BenNington \\ Nelson Center for Climatic Research, University of Wisconsin-Madison, Madison, Wisconsin
}

(Manuscript received 15 December 2011, in final form 29 November 2012)

\begin{abstract}
A historical simulation (1976-2002) of the Abdus Salam International Centre for Theoretical Physics Regional Climate Model, version 4 (ICTP RegCM4), coupled to a one-dimensional lake model, is validated against observed lake ice cover and snowfall across the Great Lakes Basin. The model reproduces the broad temporal and spatial features of both variables in terms of spatial distribution, seasonal cycle, and interannual variability, including climatological characteristics of lake-effect snowfall, although the simulated ice cover is overly extensive largely due to the absence of lake circulations. A definition is introduced for identifying heavy lake-effect snowstorms in regional climate model output for all grid cells in the Great Lakes Basin, using criteria based on location, wind direction, lake ice cover, and snowfall. Simulated heavy lake-effect snowstorms occur most frequently downwind of the Great Lakes, particularly to the east of Lake Ontario and to the east and south of Lake Superior, and are most frequent in December-January. The mechanism for these events is attributed to an anticyclone over the central United States and related cold-air outbreak for areas downwind of Lakes Ontario and Erie, in contrast to a nearby cyclone over the Great Lakes Basin and associated cold front for areas downwind of Lakes Superior, Huron, and Michigan.
\end{abstract}

\section{Introduction}

A prominent meteorological phenomenon in the Great Lakes Basin (GLB) during late autumn and winter is lakeeffect snow. Downwind of each of the five Great Lakes, mean annual snowfall exceeds $250 \mathrm{~cm}$ (Eichenlaub 1979),

\footnotetext{
* Supplemental information related to this paper is available at the Journals Online website: http://dx.doi.org/10.1175/MWRD-11-00369.s1.

${ }^{+}$Nelson Institute Center for Climatic Research Publication Number 1131.

Corresponding author address: Michael Notaro, University of Wisconsin-Madison, Center for Climatic Research, 1225 West Dayton St., Madison, WI 53706.

E-mail: mnotaro@wisc.edu
}

largely associated with lake-effect snowfall. When a cold, dry continental air mass from Canada passes over the relatively mild lakes in late autumn and winter, turbulent fluxes of heat and moisture destabilize the air mass and increase its moisture content, enhancing cloudiness and precipitation on the lee side of the lakes (Wiggin 1950; Eichenlaub 1970, 1979; Holroyd 1971; Pease et al. 1988; Leathers and Ellis 1993; Niziol et al. 1995; Ballentine et al. 1998; Kristovich and Laird 1998). Common morphologies of Great Lake-induced mesoscale circulations include the following: widespread coverage (Kristovich and Laird 1998), shoreline bands (Hjelmfelt and Braham 1983), midlake bands (Passarelli and Braham 1981), and mesoscale vortices (Laird 1999). Convective snowbands are typically narrow (5-20 km wide) and elongated (50$300 \mathrm{~km}$ long; Ballentine et al. 1998), producing the heaviest snowfalls within $150 \mathrm{~km}$ of the lake shoreline 
(Dewey 1979). Lake-effect snowfall in the GLB is usually most intense in December-January (Braham and Dungey 1984) and diminishes with ice cover formation, which dampens heat and moisture exchanges between the lake and atmosphere (Niziol et al. 1995). Ice cover is typically most extensive during FebruaryMarch (Assel 1990, 1999). Lake Erie is normally mostly ice covered in January, while the other lakes maintain some open water year-round (Assel et al. 2002; Assel 2005). Lake ice regulates lake-effect snowfall and exchanges of energy, moisture, and gases with the atmosphere (Brown and Duguay 2010).

An increase in lake ice cover typically results in a linear decline in latent heating and nonlinear decline in sensible heating (Gerbush et al. 2008), reducing the likelihood for lake-effect snowfall. However, even with extensive lake ice cover, lake-effect snowfall can still occur (Cordeira and Laird 2008). Lake ice cover can influence the formation of mesoscale circulation features (Laird and Kristovich 2004), although such impacts remain poorly understood.

The following ingredients are considered in lakeeffect snow forecasts: lake-air temperature contrast as a measure of instability, wind direction and speed as a determination of fetch, lower-tropospheric wind shear (minimal directional shear is preferable), lake ice cover, vapor pressure gradient over the lake, presence and strength of a low-level capping inversion (which can prevent convection), and amplitude of the midtropospheric wave train (Sheridan 1941; Wiggin 1950; Lavoie 1972; Dewey 1979; Niziol 1987; Hjelmfelt 1990; Byrd et al. 1991; Ballentine et al. 1992; Reinking et al. 1993; Niziol et al. 1995; Mahoney and Niziol 1997; Kunkel et al. 2002). The unique location, orientation, and shape of each of the Great Lakes make it challenging to develop a standard technique for forecasting lake-effect snow across the basin (Niziol 1987).

Heavy lake-effect snowstorms produce dramatic societal impacts, with hazards to life and property. These extreme weather events cause hazardous driving conditions; cancellations of school, flights, and events; and high snow-removal expenditure, with broad impacts on agriculture, education, transportation, commerce, utilities, infrastructures, water supply, hydroelectric generation, and recreation (Chagnon 1979; Norton and Bolsenga 1993; Schmidlin et al. 1992; Schmidlin 1993; Kunkel et al. 2002). During the twentieth century, annual snowfall increased across the lake-effect zone of the GLB, likely due to warming lakes and diminished ice cover (Burnett et al. 2003; Kunkel et al. 2009). Between 1915 and 2002, annual snowfall in Syracuse, New York, nearly doubled, with a trend in snow depth of $+1.9 \mathrm{~cm} \mathrm{yr}^{-1}$ (Burnett et al. 2003).
Modeling studies of lake-effect snowstorms have generally been limited to simulations of a couple of days or less using models that range in complexity from primitive equation models (Ellenton and Danard 1979; Ballentine 1982) to cloud-resolving models (Maesaka et al. 2006) to mixed-layer models (Lavoie 1972) to mesoscale models (Hjelmfelt 1990; Warner and Seaman 1990; Bates et al. 1993; Sousounis and Fritsch 1994; Ballentine et al. 1998; Tripoli 2005; Shi et al. 2010). These modeling case studies have led to vital insights into the key environmental factors that trigger lakeeffect snowfall in the GLB. However, modeling studies of lake-effect snowstorms on the climate time scale using regional climate models (RCMs) are blatantly absent among the scientific literature, yet vitally needed in light of the observed increase in lake-effect snowfall and uncertainty of future climate change's impact on the frequency and spatial and temporal distribution of these weather events.

Using an extremely coarse global climate model $(\mathrm{GCM})$ with $8^{\circ} \times 10^{\circ}$ spatial resolution, Cohen and Allsopp (1988) inferred that snowfall would decrease downstream of Lakes Huron and Ontario under a double- $\mathrm{CO}_{2}$ scenario. Clearly, such a model would be insufficient to represent the individual Great Lakes or actual lake-effect snowstorms. Kunkel et al. (2002) attempted to project twenty-first century changes in the frequency of lake-effect snowstorms off of Lake Erie using output from two coarse GCM. They identified six weather conditions that are closely tied to such events, including wind speed in excess of $6 \mathrm{~m} \mathrm{~s}^{-1}$, surface wind direction from south-southwesterly to west-northwesterly, surface air temperature between $-10^{\circ}$ and $0^{\circ} \mathrm{C}$, lake surface to air temperature difference in excess of $7^{\circ} \mathrm{C}$, lake surface to 850-hPa air temperature difference in excess of $15^{\circ} \mathrm{C}$, and an amplified midtropospheric wave train. Kunkel et al. (2002) then investigated projected changes in the frequency of these favorable environmental conditions in GCM output for the late twentieth and late twenty-first centuries. They concluded that lake-effect snowstorms downwind of Lake Erie are likely to become less abundant. However, no modeling study has directly simulated heavy lake-effect snowstorms and their projected future trend in occurrence; the ideal tool for such an analysis would be a high-resolution RCM coupled to an interactive lake module.

In the current study, a 25-km RCM with an interactive lake module is applied to examine heavy lake-effect snowstorms in the GLB. Spatial and temporal patterns of simulated snowfall and lake ice are evaluated against observations, including characteristics of their seasonal cycle and interannual variability. A definition for identifying simulated heavy lake-effect snowstorms is developed, 
based on fundamental concepts of lake-effect snowfall from former studies, and applied to produce a climatology of these cold season extreme events. The mechanisms behind these heavy lake-effect snowstorms are explored in the RCM and observations. The data and methods, including a description of the RCM, are presented in section 2. Results are given in section 3, while the discussion and conclusions are provided in section 4 .

\section{Data and methods}

\section{a. Model description}

Lake-effect snowfall in the GLB is examined using the Abdus Salam International Centre for Theoretical Physics Regional Climate Model, version 4 (ICTP RegCM4; Pal et al. 2007; Elguindi et al. 2011; Giorgi et al. 2012). Bates et al. (1993) recognized the capability of its earlier version, RegCM1, at capturing lake-effect snow downwind of the Great Lakes in a 10-day simulation in late December. They found that the spatial distribution of simulated snowfall improved as the grid spacing was reduced from 60 to $15 \mathrm{~km}$ (Bates et al. 1993); at the $15-\mathrm{km}$ resolution, narrow lake-effect snowbands downwind of Lake Michigan, which is the lake with the shortest westerly wind fetch, were best captured. Because of the high computational requirements of RCMs, an increase in spatial resolution tends to come at the expense of simulation duration, so a compromise between grid spacing and simulation length is needed. Bates et al. (1995) validated a two-year climate simulation of RegCM2 across the GLB, although not focusing on lake-effect snowfall. The mean simulated temperature and precipitation were characterized by small biases compared to observations and reanalysis, particularly during winter. The reasonable performance of early versions of RegCM motivated the choice of this RCM in the current study.

The dynamical core of RegCM4 is based on the fifthgeneration Pennsylvania State University-National Center for Atmospheric Research (PSU-NCAR) Mesoscale Model (MM5; Grell et al. 1994). RegCM4 is a compressible, finite-difference model using vertical sigma coordinates and constrained to hydrostatic balance. The model by default contains 18 sigma levels. The radiative transfer scheme is based on the NCAR Community Climate Model, version 3 (CCM3; Kiehl et al. 1996), with a solar component that applies the delta-Eddington approximation. The boundary layer physics is based on a nonlocal vertical diffusion scheme by Holtslag et al. (1990). Resolvable-scale precipitation and nonconvective clouds are treated by a subgrid explicit moisture (SUBEX) scheme (Pal et al. 2000), while the cumulus convection scheme addresses smaller-scale precipitation. In the current study, convective precipitation is parameterized by the Grell (1993) scheme, in which clouds are characterized by two steady-state circulations related to an updraft and a downdraft. Based on test simulations, the Grell scheme outperformed the Kuo (Anthes 1977) convective scheme in the GLB. To reduce a simulated wet bias, the rate of subcloud evaporation used in the Grell scheme, known as "cevap," is decreased from 0.0010 to 0.0008 (Torma et al. 2011; Giorgi et al. 2012); the result is a modest $5 \%$ reduction in simulated annual precipitation. The cumulus closure scheme of Fritsch and Chappell (1980) is applied, which relates convection to the degree of instability. The default land surface model for RegCM4 is the Biosphere-Atmosphere Transfer Scheme (BATS; Dickinson et al. 1986, 1993) with three soil layers and 20 land cover/vegetation classes. BATS addresses the role of vegetation and soil moisture in modifying land-atmosphere exchanges of momentum, water vapor, and energy.

In the current study, RegCM4 is interactively coupled to a one-dimensional, energy-balance lake model (Hostetler and Bartlein 1990), which accounts for vertical heat transfer within a lake column by eddy diffusion and convective mixing/overturning. By coupling the regional model to an interactive lake model, rather than fixing the lake surface temperatures based on nearby Atlantic Ocean sea surface temperatures, the model should generate more reasonable lake temperatures and allow for critical lake feedbacks to the atmosphere (Bates et al. 1993). A lake ice submodel, based on parameterizations by Patterson and Hamblin (1988), is included (Hostetler 1991), which also treats snow on lake ice. The lake model does not consider advective, horizontal heat transfer between neighboring lake points or vertical heat transfer between the lake bottom and lake water. RegCM provides air temperature, vapor pressure, wind speed, surface shortwave and longwave radiation fluxes, and snowfall to the lake model. The lake model computes a vertical lake temperature profile and returns the lake surface temperature and ice cover to RegCM4. Sensible and latent heat fluxes from the lake are calculated following the BATS parameterizations using bulk aerodynamic formulas (Dickinson et al. 1993); an increase in ice thickness results in diminished turbulent fluxes from the lake. The vertical resolution of the lake model is $1 \mathrm{~m}$. Lake depths vary spatially based on bathymetry data. Great Lakes' temperatures and ice cover, as simulated by this one-dimensional lake model, were validated by Hostetler et al. (1993) and Bates et al. (1995).

As outlined by Bennington et al. (2013, manuscript submitted to J. Climate), several corrections are applied to the one-dimensional lake model in RegCM4. Based 
on the study by Hakanson (1995), a more realistic empirical equation for computing shortwave extinction coefficients $\eta\left(\mathrm{m}^{-1}\right)$ by depth $d(\mathrm{~m})$ is imposed, $\eta=1.1925 d^{-0.424}$. Deeper lakes normally have less mineral and biotic particles, including algae, and so the light can penetrate deeper into the lake, justifying a smaller vertical extinction coefficient. Sunlight in biologically active shallow lakes often is absorbed in the upper layers. For example, extinction coefficients at depths of 25,75 , and $125 \mathrm{~m}$ are reduced from $0.70,0.50$, and 0.30 in the original code to $0.30,0.19$, and 0.15 in the revised model, which are closer to observed (Scavia et al. 1986; Guildford et al. 1994; Hakanson 1995; Sterner 2010). By reducing the extinction coefficients, the shortwave radiation is able to penetrate deeper into the lake, so the mixed layer deepens and the warm bias in summertime lake surface temperatures (also noted by Martynov et al. 2012) is diminished. The portion of shortwave radiation not absorbed by the snow and ice layers is now permitted to warm the lake. The lake convective scheme is modified, such that the presence of unstable layers results in a local mixing and not a mixing of the entire column. The one-dimensional Hostetler lake model is known to underpredict mixing for deep lakes (Perroud et al. 2009; Martynov et al. 2010; Stepanenko et al. 2010). To address the absence of lake currents and underprediction of mixing, the lake eddy diffusivity is substantially enhanced for deep lake points, following Subin et al. (2012). Finally, the melting and growing calculations for ice cover are corrected, ensuring that energy is now fully conserved in the ice model. Because of these improvements to the lake model, the deep lake points can now reasonably stratify and develop ice cover, and the interannual sensitivity of lake surface temperatures and lake ice cover is greatly enhanced to become more like observations.

\section{b. Experiment design}

The model setup includes $25-\mathrm{km}$ horizontal grid spacing $(2850-\mathrm{km}$ by $3550-\mathrm{km}$ domain, centered on the Great Lakes; Fig. 1). The applied domain is expanded to the northeast and south, compared to the Great Lakes studies by Notaro et al. (2013) and Vavrus et al. (2013), in order to better capture moisture from the Gulf of Mexico and to shift the northern and eastern buffer zone (and its associated biases in moisture convergence and precipitation) farther from the lakes. Much of the region is characterized by low elevation, except for the Appalachians Mountains. Despite the fairly simple topography in the domain, a high spatial resolution is necessary to accurately represent the individual Great Lakes and capture patterns of lake-effect snowfall. Prior studies have demonstrated that a horizontal resolution of

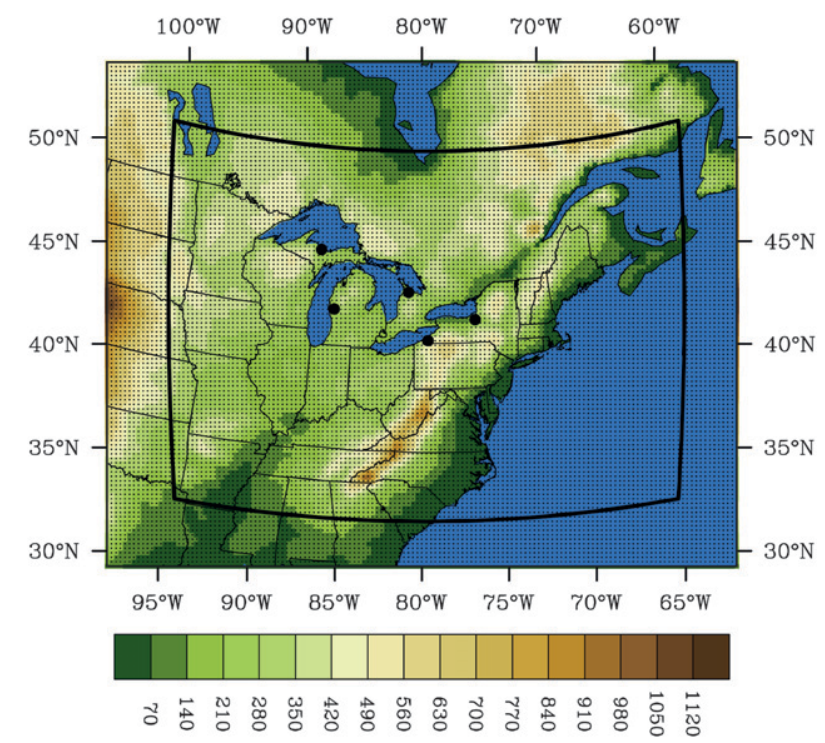

FIG. 1. Simulation domain, with shading for elevation (m) and small dots for the $25-\mathrm{km}$ grid. The inner domain, within the buffer zone, is shown with the thick black box. Large black dots represent the following cities (west to east): Marquette, MI; Hesperia, MI; Owen Sound, Ontario, Canada; Sherman, NY; and Baldwinsville, NY.

20-30 km permits a successful simulation of lake-effect snow (Hjelmfelt and Braham 1983; Warner and Seaman 1990; Sousounis and Fritsch 1994; Ballentine et al. 1998) at the meso- $\beta$ scale, justifying the selection of $25-\mathrm{km}$ grid spacing. The heaviest lake-effect snowfalls, or "megastorms," are typically produced by type-I wind-parallel snowbands (Hill 1971) from the Niziol et al. (1995) classification. Type-I lake-effect events are characterized by long fetch, with the wind blowing along the long axis of a lake, and snowband dimensions of $20-50-\mathrm{km}$ width and $50-200-\mathrm{km}$ length. Such broad, meso- $\beta$ features of lakeeffect snow (Orlanski 1975) should be captured by a 25-km RegCM4 simulation, but not individual convective bands. The Great Lakes are represented by 410 grid cells, consisting of 141 for Superior, 96 for Huron, 31 for Ontario, 100 for Michigan, and 42 for Erie. This is roughly 6 times the number of lake points as used by Bates et al. (1995) in their earlier RegCM study.

The initial and lateral boundary conditions (LBCs) are obtained from the National Centers for Environmental Prediction (NCEP)-NCAR reanalysis (Kalnay et al. 1996) and the Global Sea ice and Sea Surface Temperature dataset from the Met Office (Rayner et al. 1996). The LBCs data are 6-hourly on a $2.5^{\circ} \times 2.5^{\circ}$ grid. The buffer zone has a width of 15 grid cells and uses a linear relaxation scheme for LBCs. The historical simulation covers from May 1975 to December 2002. The first eight months are used to spin up the soil moisture and lake temperatures. 
Simulated snowfall amounts are computed based on outputted air temperature $T_{a}\left({ }^{\circ} \mathrm{C}\right)$ and the water equivalent of new snowfall $P_{n}(\mathrm{~mm})$, following the approach of Anderson (1976, 2006). Falling precipitation is assumed to be snowfall when $T_{a}<0^{\circ} \mathrm{C}$. The depth of new snow $H_{n}(\mathrm{~cm})$ is estimated as $H_{n}=0.1 P_{n} / \rho_{n}$, where $\rho_{n}$ is the density of new snow $\left(\mathrm{g} \mathrm{cm}^{-3}\right)$. When $T_{a} \leq-15^{\circ} \mathrm{C}$, the density is assigned to $0.05 \mathrm{~g} \mathrm{~cm}^{-3}$. Otherwise, the following formula is applied: $\rho_{n}=0.05+$ $0.0017\left(T_{a}+15\right)^{1.5}$. For further model evaluation, we estimate the climatology of snow liquid water content for the model and 15 observation stations, downwind of the Great Lakes, by considering precipitation totals on days when the daily mean temperature is at or below freezing.

\section{c. Datasets}

Observed daily spatial and temporal estimates of percent ice cover across the Great Lakes for 1976-2002 are obtained from the National Oceanic and Atmospheric Administration (NOAA) Great Lakes Ice Atlas (Assel 2003), based on data from the National Ice Center (1995-2002) and Canadian Ice Service (1976-94). In this atlas, the Great Lakes are represented by 38203 grid cells. Daily and monthly snowfall measurements at weather stations for 1976-2002 are retrieved from the U.S. High-Resolution Cooperative Dataset from the National Climatic Data Center (NCDC) and from Environment Canada's climate archive. A subset of daily maximum and minimum temperature and precipitation for 15 stations is extracted from these datasets for estimating snow liquid water content. The Great Lakes ice thickness database from NOAA's Great Lakes Environmental Research Laboratory (GLERL) includes periodic lake ice thickness measurements at 121 coastal locations for 1977-79. The North American Regional Reanalysis (NARR; Mesinger et al. 2006) at 32-km spatial resolution is the source of daily sea level pressure and $10-\mathrm{m}$ wind components. Archived daily weather maps are obtained from the online NOAA Central Library.

\section{Results}

\section{a. Great Lakes ice cover}

Given that lake ice can hinder the development of lake-effect snow, it is critical for this study that RegCM4 can produce reasonable temporal and spatial patterns of Great Lakes ice cover. To evaluate the simulated lake ice, the climatological mean ice cover is compared between RegCM4 and the Great Lakes Ice Atlas for 19772002 (Fig. 2). RegCM4 outputs daily ice thickness, as opposed to the ice atlas, which contains percent ice cover for each grid cell (spatial fraction of each grid box covered with ice). For the purpose of comparison, based on daily model output, a lake grid cell is either assigned to be $100 \%$ ice covered if the ice thickness is at least $2 \mathrm{~cm}$ or assigned to be $0 \%$. Results are largely insensitive to this 2-cm threshold.

RegCM4 produces a fair representation of the spatial distribution and seasonal evolution of Great Lakes ice cover, although the absence of horizontal mixing and ice movement in the lake model is the likely cause for an excessive and overly persistent ice cover. Because of the lack of horizontal mixing in the model, which can break up developing ice, the Great Lakes ice season commences too early in RegCM4. Ice begins to accumulate in December along the northern shores of Lakes Superior, Huron, and Ontario and Georgian Bay (Figs. 2a,f) for extremely shallow, fringe lake points; these highly localized ice anomalies should have minimal impact on total turbulent fluxes and resulting lake-effect snowfall. In fact, Vavrus et al. (2013) found that the model can accurately reproduce the timing and spatial pattern of past heavy lake-effect snowstorms, with most case studies in December. By January, both the model and observations show ice cover primarily along the lakeshores and the shallowest lake, Erie (Figs. 2b,g). Lake Erie is nearly completely frozen in both the observations and model by February (Figs. 2c,h). While extensive ice cover is observed across Lake Superior in FebruaryMarch, this large lake is characterized by a pronounced circulation, which tends to prevent a complete freezeover. The absence of a three-dimensional circulation in the model causes an overly extensive ice cover formation (Figs. 2c,h). In March, simulated and observed ice cover begins to break up, so that by April, the lakes are largely open (Figs. 2d,e,i,j). Over the Great Lakes only, the spatial correlations between simulated and observed percent ice cover are $0.58,0.71,0.66$, and 0.59 for December, January, February, and March, respectively (all $p<0.1$ ).

For each lake, the seasonal cycle of ice cover is compared between RegCM4 and the observational ice atlas (Fig. 3, also see supplemental Fig. S1). Both the observed and simulated percentage ice cover peak in February for all lakes. The simulated ice cover over the Great Lakes exhibits a mean bias of $+20 \%$ during the early ice season in December-January and $+31 \%$ during the peak of the ice season in February-March, particularly over Lakes Superior and Ontario. The mean biases in simulated ice cover for October-May ranges from $+11 \%$ for Lake Huron to $+20 \%$ for Lake Superior. Based on a minimum criterion of $1 \mathrm{~cm}$ in the model or $10 \%$ in the observations, the mean ice cover duration is computed for each lake. Averaged across all of the Great Lakes, the mean ice cover duration is 54 days in 

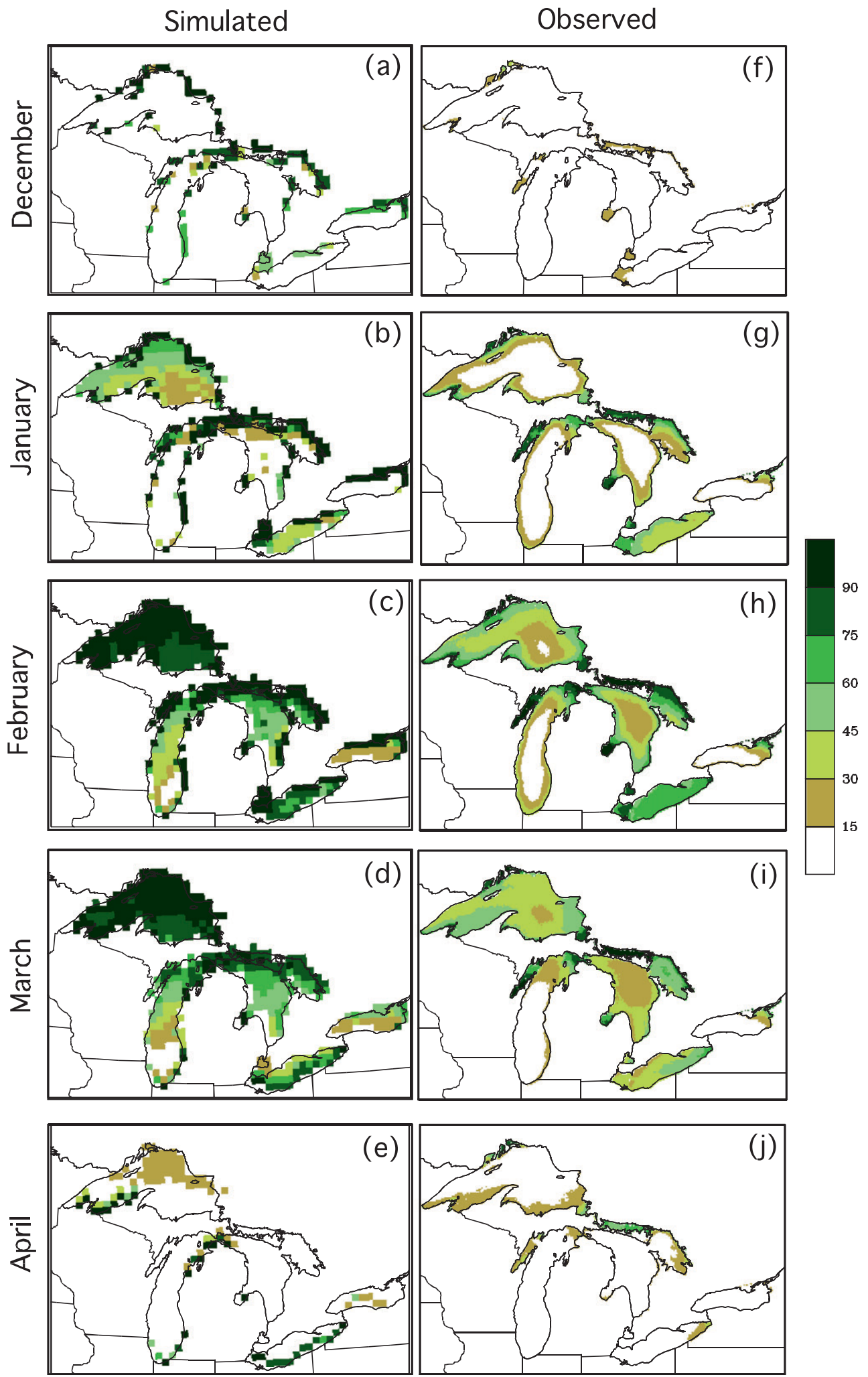

FIG. 2. Mean (a)-(e) simulated and (f)-(j) observed percent ice cover across the Great Lakes for (a),(f) December; (b),(g) January; (c),(h) February; (d),(i) March; and (e),(j) April of 1977-2002. Observations are retrieved from the NOAA Great Lakes Ice Atlas. 

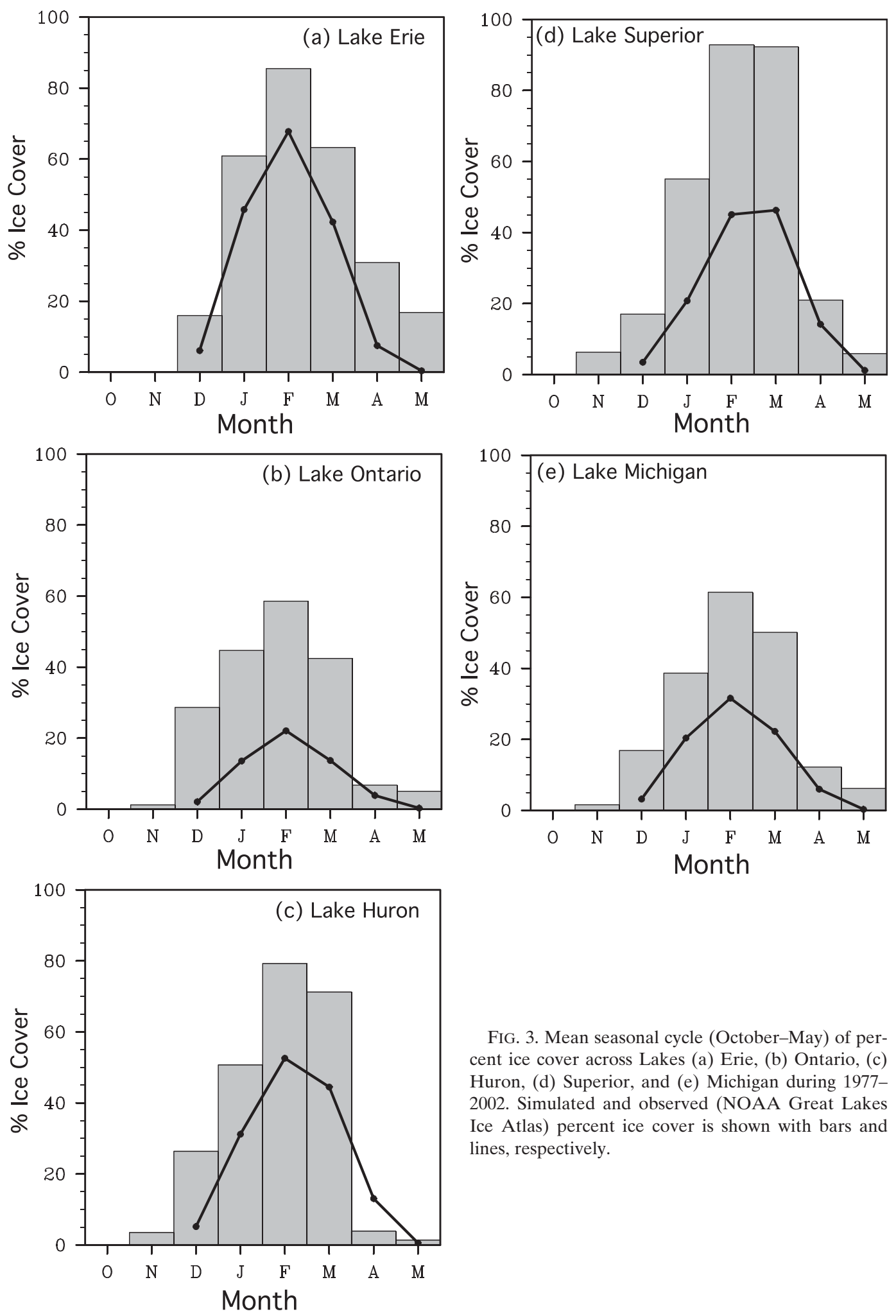

FIG. 3. Mean seasonal cycle (October-May) of percent ice cover across Lakes (a) Erie, (b) Ontario, (c) Huron, (d) Superior, and (e) Michigan during 19772002. Simulated and observed (NOAA Great Lakes Ice Atlas) percent ice cover is shown with bars and lines, respectively. 
the observations and 78 days in the model, with biases that range from +13 days for Lake Huron to +32 days for Lake Superior. The absence of lake currents is the likely cause for overly persistent ice cover on Lake Superior, since movement of the water normally breaks up developing ice in late autumn and existing ice in early spring. Martynov et al. (2010) likewise found that the one-dimensional Hostetler lake model produces too long of an ice season for Lake Superior, in conjunction with an overly rapid cooling of the lake surface in autumn.

Simulated ice thicknesses during 1977-79 are compared at coastal lake points with measurements from the Great Lakes ice thickness database. Both simulated and observed ice thicknesses for all five lakes peak during February-March. Averaged lakewide, the simulated peak ice thickness in February ranges from $42 \mathrm{~cm}$ on Lake Michigan to $58 \mathrm{~cm}$ on shallow Lake Erie. Along the lakeshores, the mean ice thicknesses during February-March are 55, 41, 51, 40, and $39 \mathrm{~cm}$ in the model and $34,35,34,40$, and $40 \mathrm{~cm}$ in the observations, for Lakes Superior, Huron, Ontario, Michigan, and Erie, respectively. Simulated ice thickness for coastal regions is excessive by $21 \mathrm{~cm}$ for Superior and $17 \mathrm{~cm}$ for Erie, while it closely matches observations for the remaining three lakes. The spatial pattern of simulated ice thickness is reasonable, with the thickest ice over shallow coastal waters.

Lake ice strongly regulates the seasonal cycle of lakeeffect snowfall in the GLB. Niziol et al. (1995) and Miner and Fritsch (1997) explored the observed phases of the seasonal cycle of atmospheric stability over Lake Erie. The lake-effect rain season typically occurs during August-November, when Lake Erie is warmer than the overlying air and the air temperature is high enough for precipitation to fall in liquid form. During the subsequent lake-effect snow season in November-January, the lake remains warmer than the air, resulting in continued atmospheric instability, and the lake-effect precipitation is primarily snow due to lower air temperatures. In February-March, Lake Erie is largely frozen, hindering the development of lake-effect precipitation. After ice breakup, the lake-effect stable season usually extends during April-July, with lake temperatures lower than atmospheric temperatures, which enhances atmospheric stability.

In agreement with the findings of Niziol et al. (1995) and Miner and Fritsch (1997), RegCM4 captures the timing of the lake-effect rain season, lake-effect snow season, frozen lake period, and lake-effect stable season across the Great Lakes, including Erie (Holman et al. 2012; Fig. 4). In general, the lake-effect snow season is December-March, with diminished lake-effect activity during midwinter (usually February) over Lakes Erie,
Superior, and Huron related to extensive ice cover (Figs. $4 a, c)$. During January, the mean simulated lake surface temperatures exceed that of the overlying 2-m air temperatures by $6.0^{\circ} \mathrm{C}$ for Lake Erie and $8.7^{\circ} \mathrm{C}$ for Lake Superior, leading to strong turbulent fluxes across the open portion of the lakes. Given that Lake Superior holds the greatest volume of water, its heat capacity is vast and its temperatures slowly change, thereby leading to the large thermal contrast with the overlying atmosphere during midwinter. Lake Superior contains the deepest waters and experiences the coldest air masses of the five lakes due its geographic location, supporting a prolonged, unstable lake-effect snow season from midNovember through early April. As cold air masses from Canada move southeastward across the basin, they are modified by sensible heat fluxes from Lake Superior such that these air masses are not quite as cold along their southeastward trajectory.

Despite its excess ice cover bias, RegCM4 accurately captures the year-to-year [December-May (DJFMAM)] fluctuations in Great Lakes' percent ice cover during 1976/77-2001/02 (Fig. 5a). A comparison between observed and simulated percent ice cover for the Great Lakes yields a temporal correlation of $0.95(p<0.1)$; for individual lakes, the temporal correlation ranges from 0.82 for Lake Ontario to 0.91 for Lake Huron. These high correlations are attributed to the accurate simulation of interannual variability in $2-\mathrm{m}$ air temperatures during DJFM, with a cold bias of $-0.89^{\circ} \mathrm{C}$ and high temporal correlation of 0.98 across the GLB (Fig. 5b). After removing the mean observed and simulated ice cover, RegCM4 correctly captures the sign of the anomaly in Great Lakes' ice cover in 25 out of 26 years. The mean simulated percent ice cover for DecemberMay, across the Great Lakes, exhibits a bias of $+16 \%$. The model accurately reproduces the interannual variability and range in mean December-May percent ice cover for the Great Lakes, with standard deviations of $9.9 \%$ and $10.0 \%$ and ranges of $32.6 \%$ and $36.1 \%$ for the model and observations, respectively. The observed negative trend in Great Lakes' ice cover during 1976/77$2001 / 02$ of $-0.75 \% \mathrm{yr}^{-1}$ is also well captured by the model $\left(-0.70 \% \mathrm{yr}^{-1}\right)$. This decline in ice cover corresponds to an observed and simulated warming trend in DJF of $+0.10^{\circ}$ and $+0.11^{\circ} \mathrm{Cyr}^{-1}$, respectively.

The excessive ice cover bias in RegCM4 can be attributed primarily to the lack of lake circulation and secondarily to a simulated cold bias. As evidence of this conclusion, the temporal correlation between biases in DJFM 2-m air temperature across the GLB and biases in December-May mean ice cover is $-0.67(p<0.1$; Fig. 5c). For example, cold biases of $-1.75^{\circ}$ and $-1.00^{\circ} \mathrm{C}$ during the winters of 1980/81 and 1998/99 favor substantial 

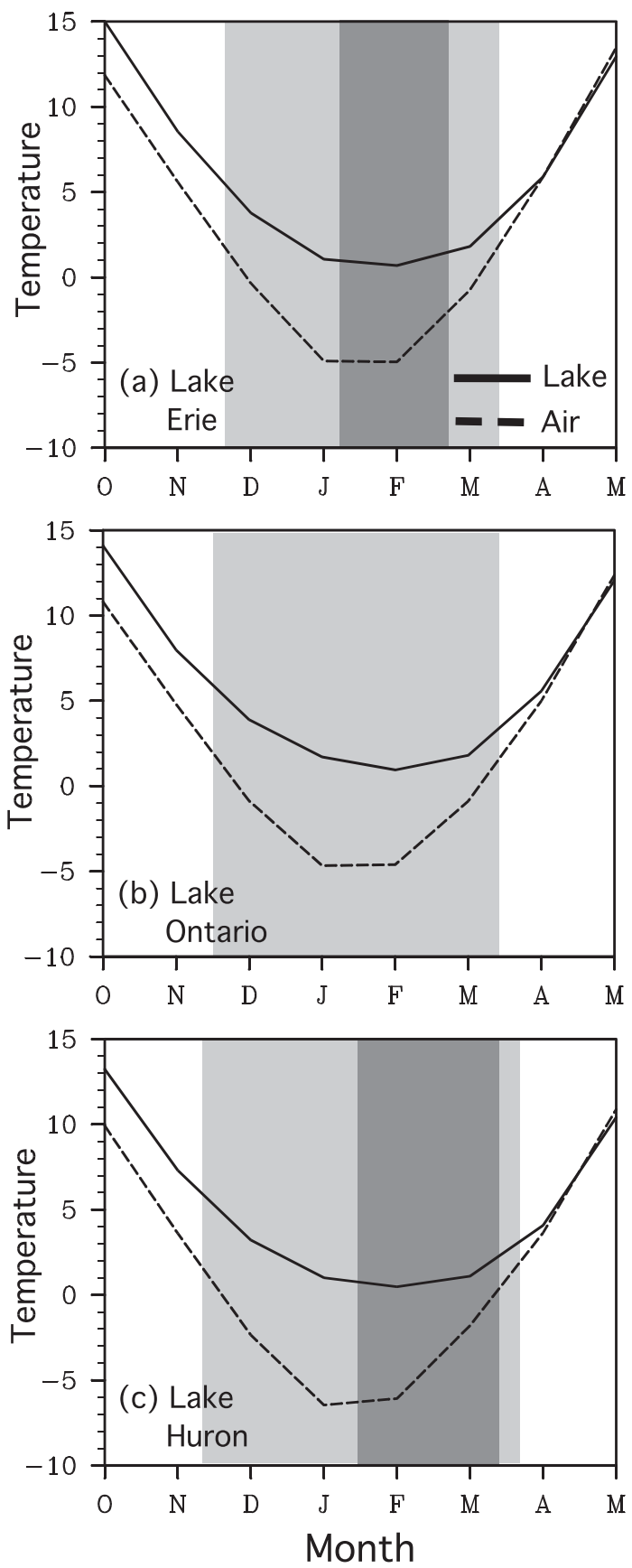
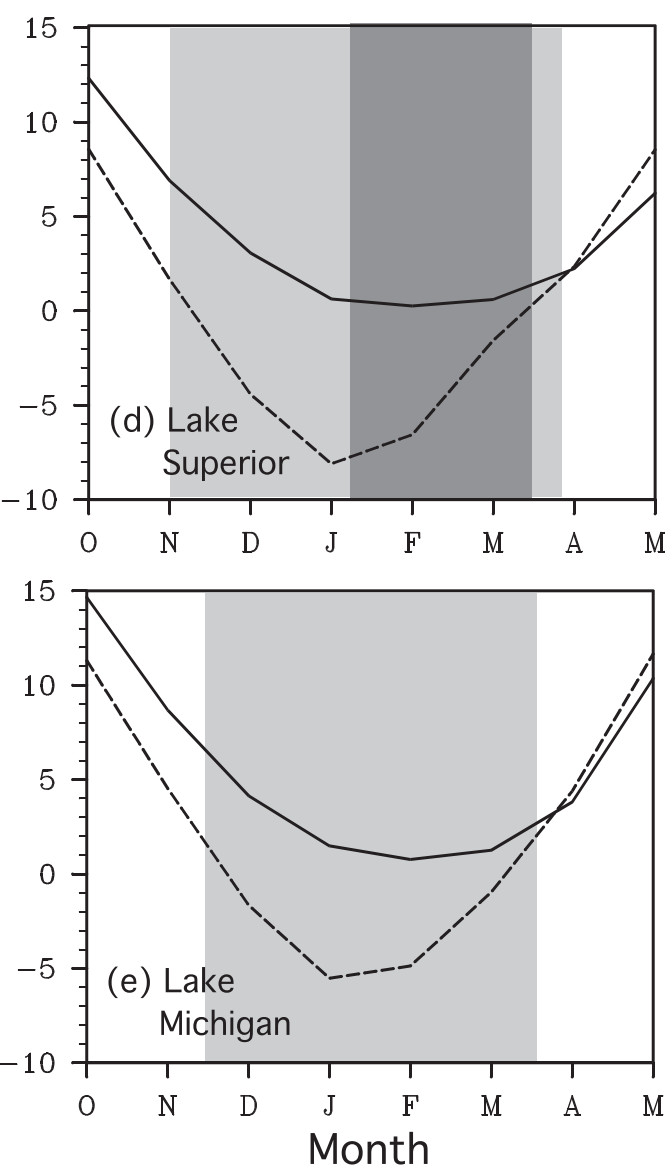

FIG. 4. Mean simulated seasonal cycle (centered on winter) of lake surface (solid) and 2-m air (dashed) temperature over Lakes (a) Erie, (b) Ontario, (c) Huron, (d) Superior, and (e) Michigan during 19772002. Light gray shading indicates the time period when the lake is warmer than the air (unstable) and the daily mean temperature is less than $2^{\circ} \mathrm{C}$ (frozen precipitation), thereby representing the lake-effect snow season. Dark gray shading indicates when the lake is typically more than $70 \%$ ice covered, limiting lakeeffect snow. ice cover biases of $+22.3 \%$ and $21.8 \%$, respectively. While the cold bias allows for excessive ice development, this excess ice cover also triggers a positive feedback, making the overlying atmosphere even colder.

\section{b. Snowfall}

The spatial distribution of annual mean snowfall is compared between RegCM4 and station observations (Fig. 6). Across the domain, the spatial correlation is
0.81 for 2880 stations $(p<0.1)$, with a simulated snowfall bias of $+26 \%$. Within the GLB $\left(40^{\circ}-50^{\circ} \mathrm{N}, 74^{\circ}-94^{\circ} \mathrm{W}\right)$, the spatial correlation is 0.75 for 833 stations $(p<0.1)$, with a bias of $+24 \%$. Across the GLB, the root-meansquare difference between observed and simulated annual snowfall is $67 \mathrm{~cm}$, with the model producing too much snowfall at $85 \%$ of the stations. All of the major lake-effect snow regions, in excess of $250 \mathrm{~cm}$, are captured by the model. RegCM4 simulates too much 
(a) DJFMAM Percent Ice Cover (Model vs. Observed)

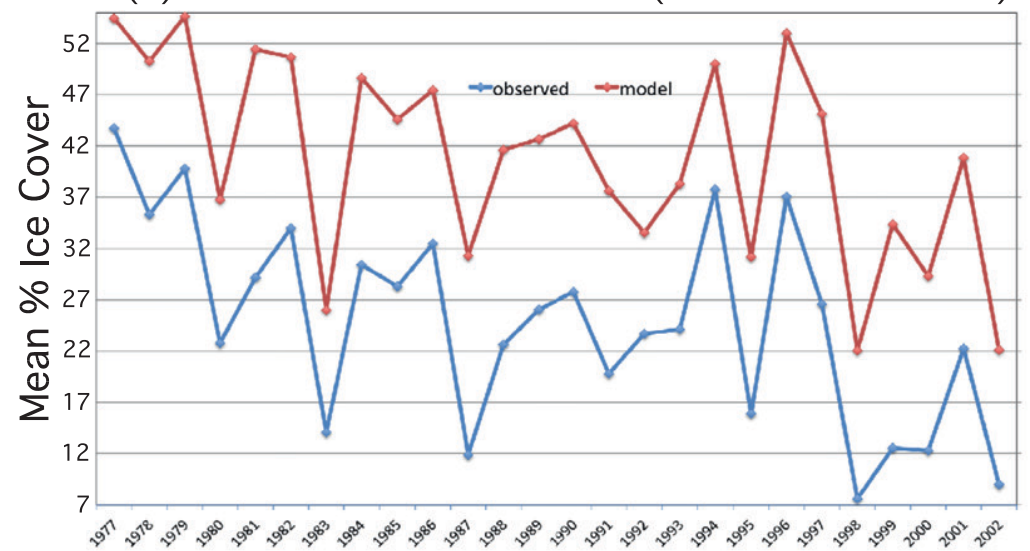

(b) DJFM 2-m Air Temperature ${ }^{\circ} \mathrm{C}$ (Model vs. Observed)

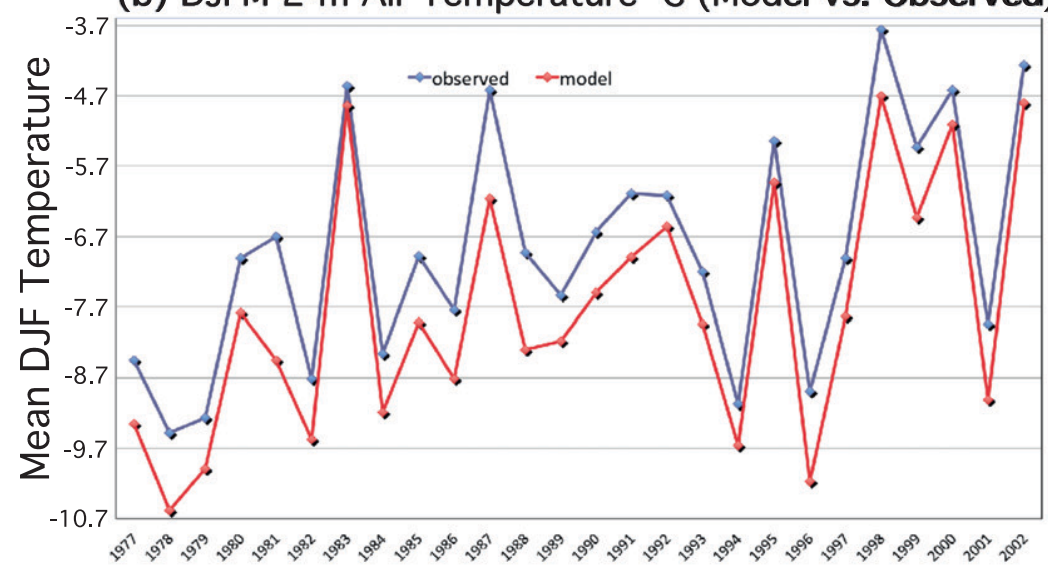

(c) Biases in 2-m Air Temperature $\left({ }^{\circ} \mathrm{C}\right)$ and Percent Ice Cover

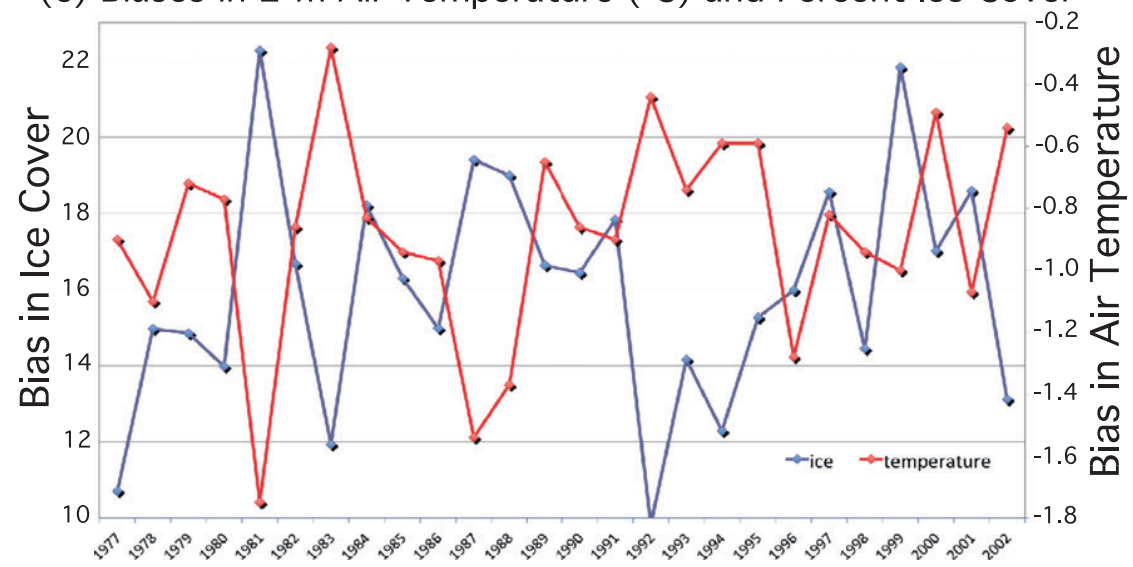

FIG. 5. (a) Observed (blue) and simulated (red) DJFMAM Great Lakes' percent ice cover during 1976/77-2001/02. Observations are from the NOAA Great Lakes Ice Atlas, using data from National Ice Center and Canadian Ice Service. The temporal correlation $(N=26 \mathrm{yr})$ is 0.95 for the raw data and 0.93 after detrending both series. Observed and simulated trends are $-0.75 \%$ and $-0.70 \% \mathrm{yr}^{-1}$, respectively. (b) Simulated (red) and observed (blue) DJFM 2-m air temperature over land in the Great Lakes Basin during 1976/77-2001/02. Observations are from the University of Delaware (Willmott and Matsuura 2000). The temporal correlation is 0.98. Both observed and simulated trends are $+0.10^{\circ}$ and $+0.11^{\circ} \mathrm{C} \mathrm{yr}^{-1}$, respectively. (c) Biases in air temperature $\left({ }^{\circ} \mathrm{C}\right.$, red, right axis) and percent ice cover (blue, left axis), with temporal correlation of -0.67 . 

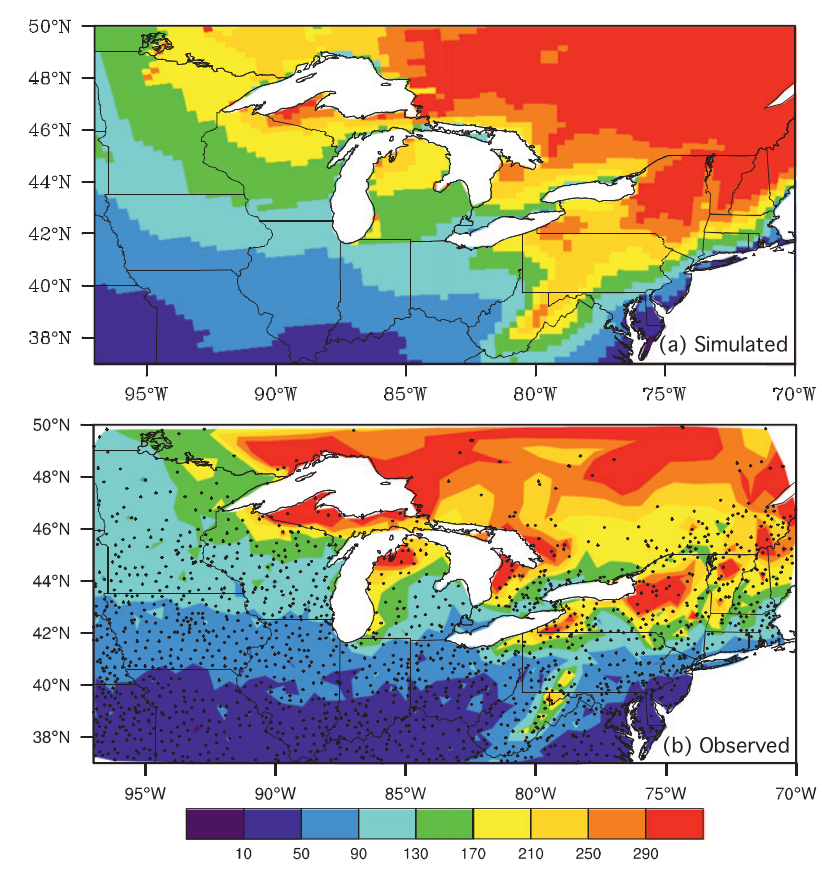

FIG. 6. Mean annual snowfall (cm) in the (a) model and (b) observations during 1976/77-2001/02. The sources of station observations are the U.S. High-Resolution Cooperative Dataset from the National Climatic Data Center and data from Environment Canada.

snowfall across lower Ontario and Quebec, Canada, by roughly $80 \mathrm{~cm}$ (although station observations are sparse there) and too little downstream of Lakes Superior and Michigan (Fig. 6), partly related to excessive ice cover (Fig. 3). A wet bias in precipitation is identified over the northeastern domain (consisting of southern Ontario and Quebec), potentially a result of excess convergence due to a discontinuity in winds between the inner domain and buffer zone; however, this is beyond the region of lake-effect snowfall and not a serious concern in the present study. The positive ice cover bias on Lake Ontario does not result in too little simulated snowfall downwind of the lake since the model appears to overemphasize the topographic enhancement of snowfall totals by the Adirondacks. Roughly $99 \%$ of the simulated DJFM precipitation in the GLB is determined by the subgrid explicit moisture scheme, with minimal convective precipitation.

The frequency of snowfall days (in excess of $1 \mathrm{~cm}$ ) is analyzed in the model and observations, and both contain maxima in excess of 50 days $\mathrm{yr}^{-1}$ downstream of the five Great Lakes, particularly south of Lake Superior (Fig. 7). Within the GLB $\left(41.0^{\circ}-49.3^{\circ} \mathrm{N}, 93^{\circ}-75^{\circ} \mathrm{W}\right)$, the observed and simulated frequencies of snowfall days are 30.4 and 39.5 days $\mathrm{yr}^{-1}$, respectively, with a spatial correlation of $0.77(p<0.1)$. The simulated maxima to (a) Simulated

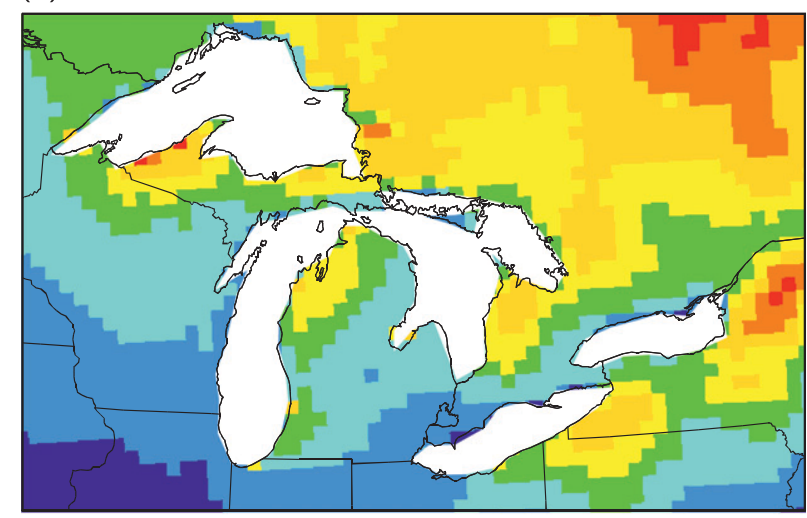

(b) Observed

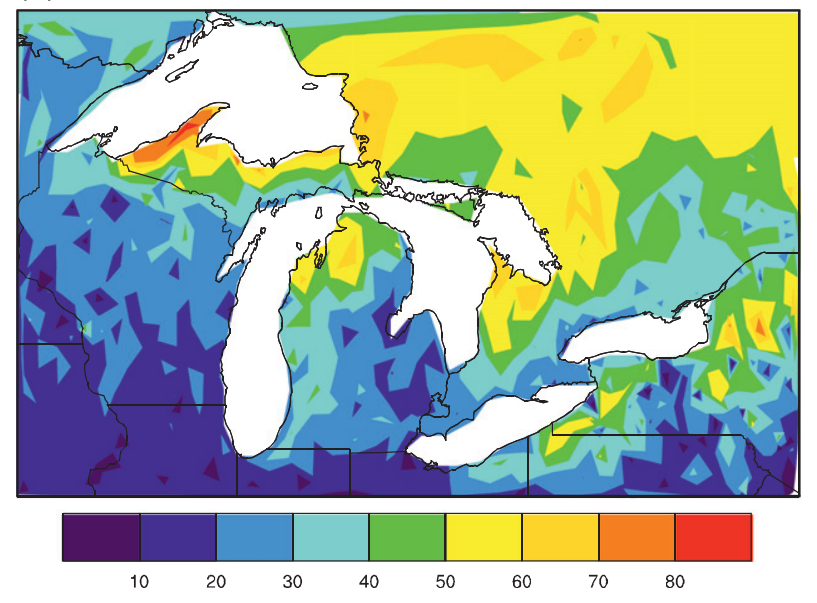

FIG. 7. Mean frequency (days per year) of daily snowfall of at least $1 \mathrm{~cm}$ in the (a) model and (b) observations during 1976/772001/02.

the south of Lake Superior and east of Lakes Ontario and Erie extend farther from the lakeshores than is observed. Consistent with the excessive simulated snowfall in southern Ontario and Quebec, the model produces too frequent snowfall days in that region. The capability of the model to capture observed snow events downstream of the Great Lakes is explored in supplemental Table S1 and the study by Vavrus et al. (2013).

Analysis of the mean snowfall seasonal cycle reveals that snowfall downstream of the Great Lakes is greatest during early winter, with observed and simulated peaks in January for all five lakes (Fig. 8). By February, ice cover is most extensive, thereby reducing lake-effect snowfall. According to both the model and observations, February snowfall is typically about $40 \%$ lower than January snowfall downstream of the Great Lakes. The simulated seasonal snowfall downwind of Lakes Superior, Michigan, Huron, and Erie is biased too low by $-21 \%$, $-13 \%,-7 \%$, and $-6 \%$, respectively, while downwind of Lake Ontario, the model produces $+27 \%$ too much 

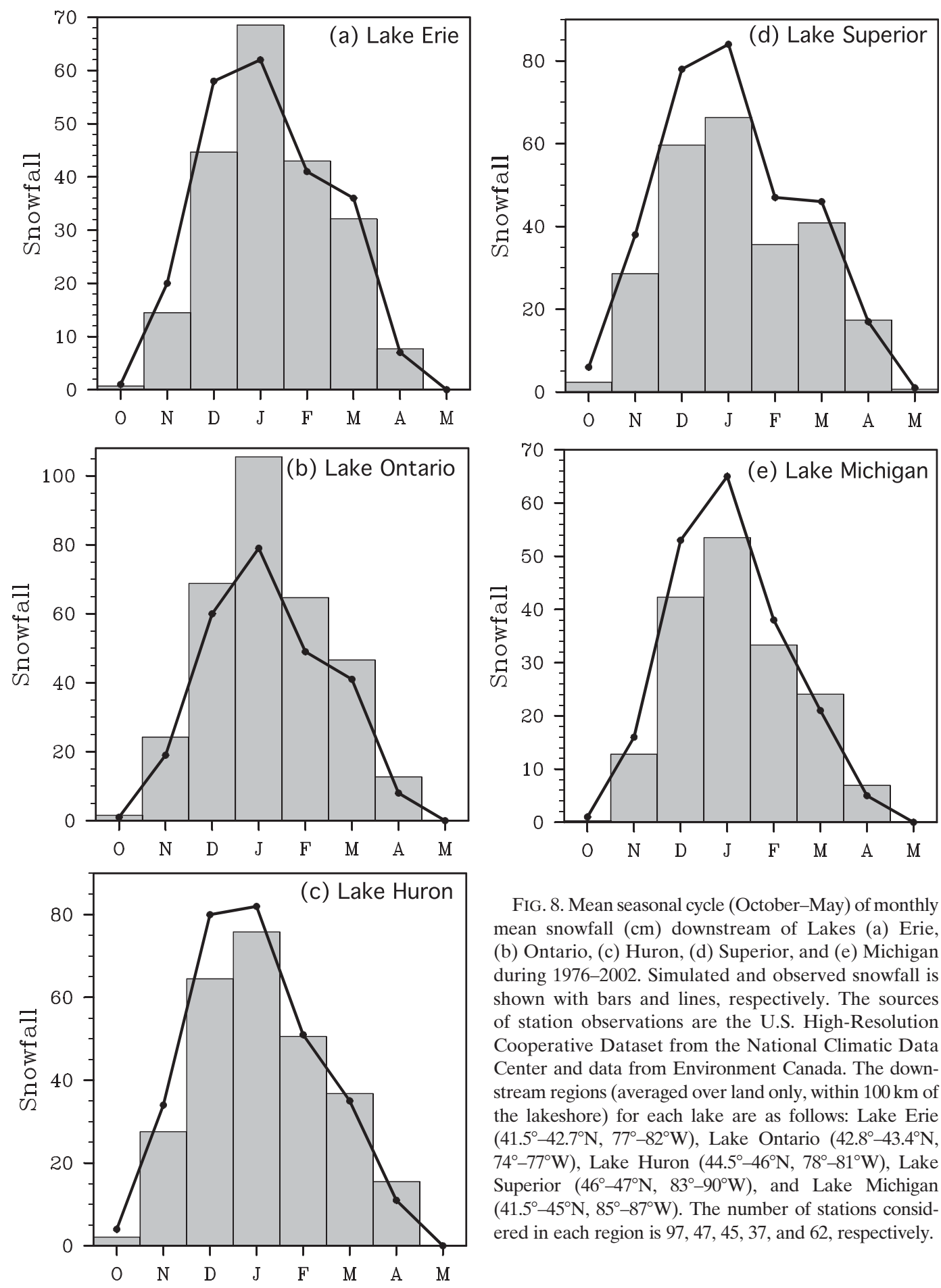

FIG. 8. Mean seasonal cycle (October-May) of monthly mean snowfall $(\mathrm{cm})$ downstream of Lakes (a) Erie, (b) Ontario, (c) Huron, (d) Superior, and (e) Michigan during 1976-2002. Simulated and observed snowfall is shown with bars and lines, respectively. The sources of station observations are the U.S. High-Resolution Cooperative Dataset from the National Climatic Data Center and data from Environment Canada. The downstream regions (averaged over land only, within $100 \mathrm{~km}$ of the lakeshore) for each lake are as follows: Lake Erie $\left(41.5^{\circ}-42.7^{\circ} \mathrm{N}, 77^{\circ}-82^{\circ} \mathrm{W}\right)$, Lake Ontario $\left(42.8^{\circ}-43.4^{\circ} \mathrm{N}\right.$, $\left.74^{\circ}-77^{\circ} \mathrm{W}\right)$, Lake Huron $\left(44.5^{\circ}-46^{\circ} \mathrm{N}, 78^{\circ}-81^{\circ} \mathrm{W}\right)$, Lake Superior $\left(46^{\circ}-47^{\circ} \mathrm{N}, 83^{\circ}-90^{\circ} \mathrm{W}\right)$, and Lake Michigan $\left(41.5^{\circ}-45^{\circ} \mathrm{N}, 85^{\circ}-87^{\circ} \mathrm{W}\right)$. The number of stations considered in each region is $97,47,45,37$, and 62 , respectively.

snowfall (bias of $+27 \mathrm{~cm}$ in January). For areas within the lake-effect zone, a greater percentage of the annual snowfall occurs during November-December (due to strong turbulent fluxes off the lakes) and a smaller percentage occurs during January-March (due to lake ice),

than in areas away from the lakeshores. A comparison between the three winters with the greatest (1976/77, 1977/78, and 1995/96) and least (1982/83, 1997/98, and 2001/02) simulated ice cover on Lake Erie reveals $130 \%$ more downwind snowfall during November-December 
and $36 \%$ less snowfall during January-March in the former years than the latter years, with minimal difference in annual totals. Clearly, extensive ice cover reduces lake-effect snowfall during mid- to late winter. Vavrus et al. (2013) examined a set of 10 heavy lakeeffect snowstorms in RegCM4, largely in December, and showed that the snowfall downstream of the Great Lakes is typically reduced by at least $80 \%$ by imposing complete ice cover on the upstream lake. Their study demonstrated that lake ice cover exerts both a thermodynamical and dynamical feedback on lake-effect snowstorms.

While the study focuses on snowfall as depth, we also evaluate the simulated snow liquid water against observed estimated at 15 locations downstream of the Great Lakes (Fig. 9). Both the observed and modeled snow liquid water peaks in January at nearly all 15 stations. The mean simulated cold-season bias is $+30 \%$, which ranges from $-11 \%$ at Wiarton, Ontario, to $+99 \%$ at Cleveland, Ohio. The observations likely suffer from significant undercatchment due to wind.

RegCM4 reproduces much of the interannual variability in annual snowfall downwind of the Great Lakes during 1977/78-2001/02 (Fig. 10). The temporal correlations between observed and simulated snowfall, downwind of each Great Lake, range from 0.75 for Lake Huron to 0.89 for Lake Superior. Even though the simulated snowfall downstream of Lake Ontario is excessive, the standard deviation of annual snowfall is nearly identical between the model $(78 \mathrm{~cm})$ and observations $(73 \mathrm{~cm})$ (Fig. 10b). Averaged among the five Great Lakes, the root-mean-square-error between the time series of simulated and observed annual snowfall is $59 \mathrm{~cm}$, which is $23 \%$ of the annual mean total. The largest simulated snowfall bias downwind of the Great Lakes, $-51 \mathrm{~cm}$ in winter 2000/01, corresponds to a positive ice cover bias of $18.6 \%$ that develops in response to $\mathrm{a}-1.07^{\circ} \mathrm{C}$ bias at $2 \mathrm{~m}$ across the basin.

Lake-lake correlations are performed to determine if the model and observations share the same degree of spatial coherence in interannual variability (1976/77-2001/ 02) of either lake ice cover or lake-effect snowfall (Table 1). The mean lake-lake correlation for December-May percent ice cover is 0.87 in the observations and 0.85 in the model. In both the model and observations, if ice cover is anomalously extensive (low) over one lake, it is very likely to be anomalously extensive (low) over the other four lakes. Meanwhile, the mean lake-lake correlation for annual snowfall, downwind of the lakes, is 0.59 in the observations and 0.77 in the model. The discrepancy is most pronounced for snowfall correlations between Lakes Ontario and Huron, which are 0.43 in the observations and 0.80 in the model.

\section{c. Heavy lake-effect snowstorms}

A regionally applicable definition for identifying heavy lake-effect snowstorms in the GLB from RCM output is presented. It is acknowledged that no perfect definition can be formulated and each component of the definition is partly subjective. For each grid cell in the GLB and each day in RegCM4 output, the following criteria are applied to determine if a heavy lakeeffect, or lake-enhanced (Eichenlaub 1979), snowstorm occurred.

1) The grid cell must be located over land and within $100 \mathrm{~km}$ of one of the Great Lakes' shorelines. The heaviest climatological snowfall amounts are typically found within $100 \mathrm{~km}$ of a Great Lake (Dewey 1979; Eichenlaub 1979).

2) For at least $6 \mathrm{~h}$, the mean $10-\mathrm{m}$ wind direction must be off one of the Great Lakes, allowing for sufficient fetch. Kunkel et al. (2002) noted the importance of wind direction for lake-effect snowstorms downstream of Lake Erie, with nearly all heavy storms occurring with wind directions of west to southwest.

3) The ice cover fraction on the lake, off which the wind is flowing, must be less than $70 \%$. Gerbush et al. (2008) found that sensible heat fluxes dramatically decline nonlinearly for percent lake ice covers in excess of $70 \%$.

4) The local daily snowfall must be at least $10 \mathrm{~cm}$, following the criterion applied by Liu and Moore (2004) for lake-effect snowstorms in southern Ontario, Canada. In RegCM4, $10 \mathrm{~cm}$ represents the top $5 \%$ of daily snowfall totals during DJFM, downwind of the Great Lakes. We justify the use of depth of new snowfall, rather than its liquid equivalent, based on previous climatological studies of heavy lakeeffect snowstorms by Kunkel et al. (2002) and Liu and Moore (2004). Likewise, Kocin and Uccellini (2004) developed a Northeast snowfall impact scale to assess societal impacts of individual snowstorms, focusing on the depth of new snowfall, mapped onto the population density that experienced the snow, beginning with a minimum snowfall criterion of $10 \mathrm{~cm}$. For some stations, snowfall is the measured variable, albeit by an array of methods (e.g., measuring sticks, snow boards, snow stakes) and its liquid equivalent is estimated with a standard 10:1 ratio (Roebber et al. 2003), particularly in older records (Kunkel et al. 2007). However, station relocations and procedural changes can make any station's meteorological record problematic (Kunkel et al. 2007).

5) The local, near-lake daily snowfall must exceed the mean nonlocal/continental snowfall, far from the lake, by at least $4 \mathrm{~cm}$. For each grid cell under consideration 

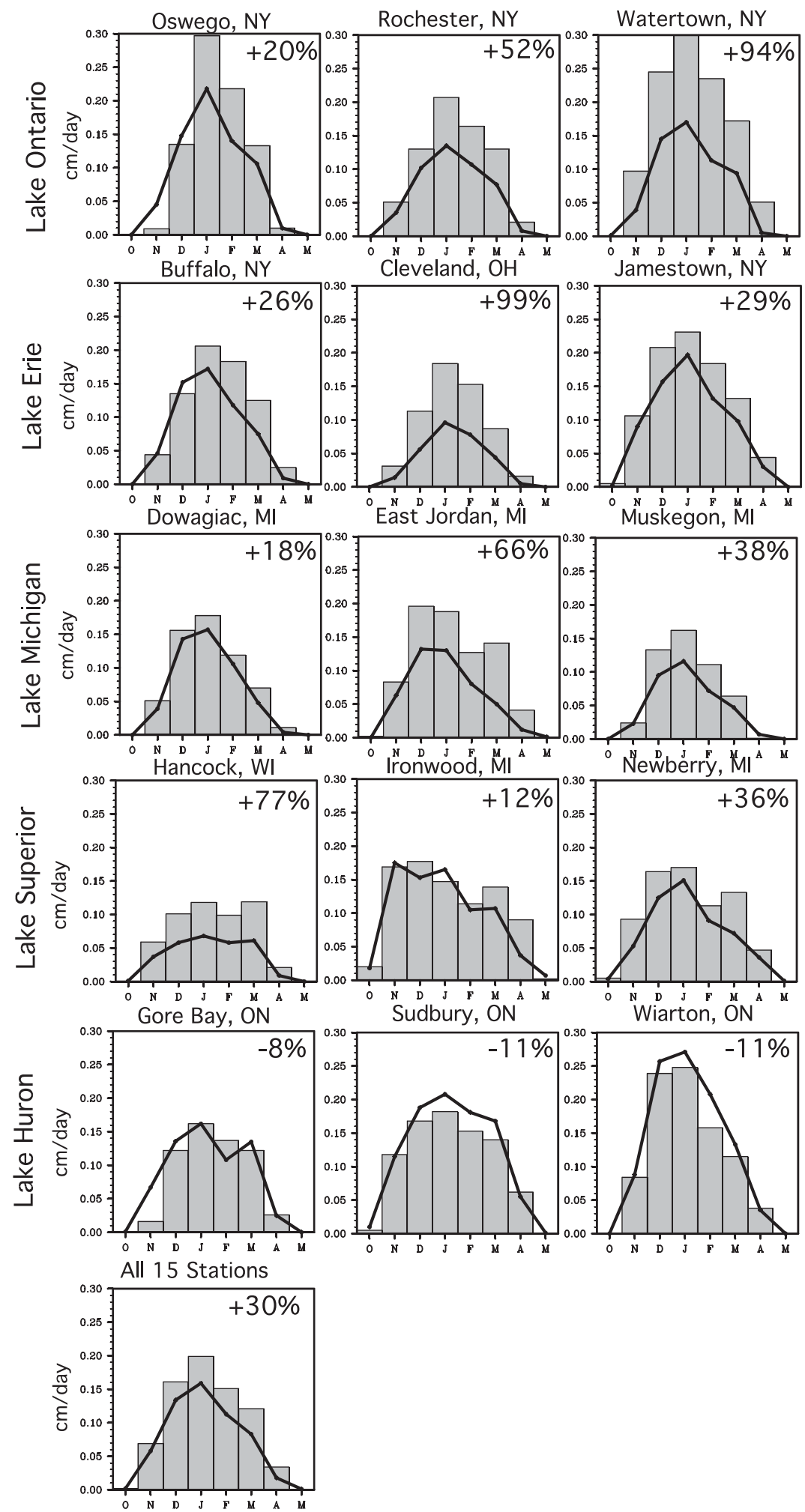

FIG. 9. Mean seasonal cycle (October-May) of monthly mean snow liquid water content $\left(\mathrm{cm} \mathrm{day}^{-1}\right)$ during 1976-2002 for three stations downstream of each of the five Great Lakes, with the average results from these 15 stations shown in the lowest graph. Simulated and observed snow liquid water content is shown with bars and lines, respectively. The sources of station observations are the U.S. High-Resolution Cooperative Dataset from the National Climatic Data Center and data from Environment Canada. 

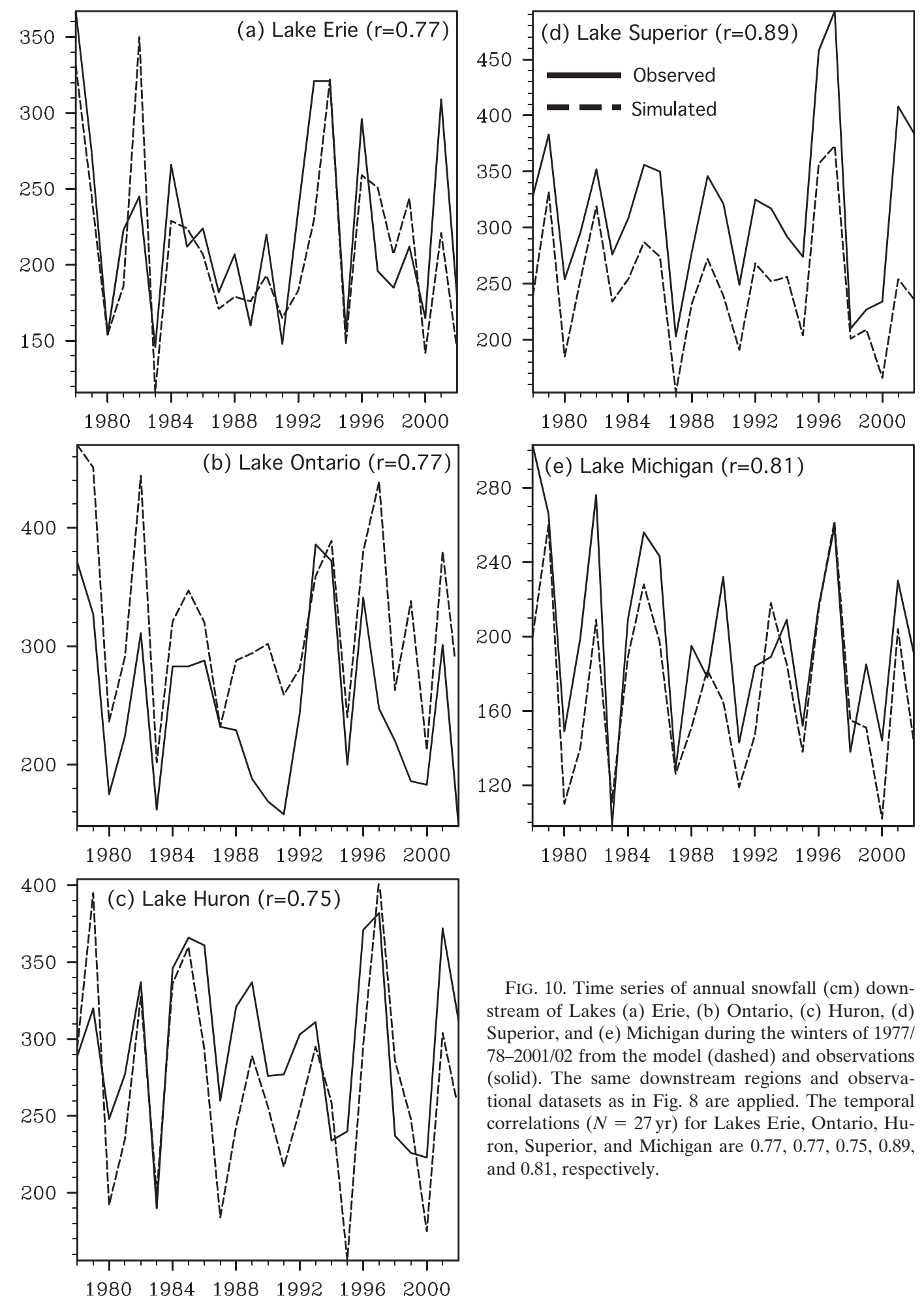

FIG. 10. Time series of annual snowfall $(\mathrm{cm})$ downstream of Lakes (a) Erie, (b) Ontario, (c) Huron, (d) Superior, and (e) Michigan during the winters of 1977/ 78-2001/02 from the model (dashed) and observations (solid). The same downstream regions and observational datasets as in Fig. 8 are applied. The temporal correlations $(N=27 \mathrm{yr})$ for Lakes Erie, Ontario, Huron, Superior, and Michigan are 0.77, 0.77, 0.75, 0.89, and 0.81 , respectively.

(within $100 \mathrm{~km}$ of a lakeshore), a moving window of 20 grid cells $(500 \mathrm{~km})$ in each direction is assigned and the mean snowfall within this box is computed for all grid cells beyond the $100-\mathrm{km}$ lake-effect zone. This value

represents the nonlocal/continental snowfall, not attributed to lake effect. Kunkel et al. (2002) considered three stations outside of the lake-effect snowbelt of Lake Erie to achieve a similar goal, requiring that 
TABLE 1. (top) Temporal correlations between annual snowfall totals downwind of pairs of lakes for the winters of 1976/77-2001/02 $(N=26 \mathrm{yr})$, from both (left) station observations and (right) model output. SUP, HUR, ONT, MIC, and ERI stand for Lakes Superior, Huron, Ontario, Michigan, and Erie, respectively. The $\uparrow(\downarrow)$ identifies correlations in the model that are greater (less) than observed by at least 0.10 . (bottom) As in (top), but for percent lake ice cover.

\begin{tabular}{|c|c|c|c|c|c|c|c|c|c|c|}
\hline & \multicolumn{5}{|c|}{ Observed } & \multicolumn{5}{|c|}{ Simulated } \\
\hline & SUP & HUR & ONT & MIC & ERI & SUP & HUR & ONT & MIC & ERI \\
\hline \multicolumn{11}{|l|}{ Snow } \\
\hline SUP & 1.00 & 0.80 & 0.39 & 0.67 & 0.39 & 1.00 & 0.82 & $0.73 \uparrow$ & $0.84 \uparrow$ & $0.53 \uparrow$ \\
\hline HUR & & 1.00 & 0.43 & 0.67 & 0.36 & & 1.00 & $0.80 \uparrow$ & $0.93 \uparrow$ & $0.61 \uparrow$ \\
\hline ONT & & & 1.00 & 0.63 & 0.90 & & & 1.00 & $0.88 \uparrow$ & 0.90 \\
\hline MIC & & & & 1.00 & 0.66 & & & & 1.00 & 0.68 \\
\hline ERI & & & & & 1.00 & & & & & 1.00 \\
\hline \multicolumn{11}{|l|}{ Ice } \\
\hline SUP & 1.00 & 0.92 & 0.82 & 0.90 & 0.76 & 1.00 & 0.89 & $0.72 \downarrow$ & 0.88 & $0.89 \uparrow$ \\
\hline HUR & & 1.00 & 0.92 & 0.91 & 0.90 & & 1.00 & $0.80 \downarrow$ & 0.96 & 0.92 \\
\hline ONT & & & 1.00 & 0.93 & 0.88 & & & 1.00 & $0.83 \downarrow$ & $0.72 \uparrow$ \\
\hline MIC & & & & 1.00 & 0.80 & & & & 1.00 & 0.85 \\
\hline ERI & & & & & 1.00 & & & & & 1.00 \\
\hline
\end{tabular}

snowfall at a lake-effect station exceed that of a nonlake-effect station.

This definition of heavy lake-effect snowstorms is applied to the 1976-2002 simulation across the GLB to estimate the mean annual frequency of these cold-season weather extremes (Fig. 11). Heavy lake-effect snowstorms occur in RegCM4 roughly $1.5-3$ days $^{-1}{ }^{-1}$ in the lake-effect snowbelts to the east of each Great Lake and to the south of Lake Superior, with the greatest frequency east of Lake Ontario and south and east of Lake Superior. Downwind of each Great Lake, simulated heavy lake-effect snowstorms are most common in DecemberJanuary, with roughly $60 \%$ of such storms occurring in those two months. The preferred timing is earlier for Lake Superior (December) than Lake Ontario (January), given that Lake Ontario remains largely open, even in January. For regions downwind of Lakes Superior and Huron, only about $14 \%$ of total storms occur during February-March, because of extensive simulated ice cover (Figs. 3 and 12). Modest secondary peaks in heavy lake-effect snowstorm occurrence are noted downwind of Lakes Erie and Superior in March and April, respectively, as lake ice cover declines. The local minimum in heavy lake-effect snowstorms during February-March for Lake Superior is likely exaggerated because of excessive simulated ice cover (Fig. 3d).

Given that the third to fifth criteria applied in the heavy lake-effect snowstorm definition apply static threshold values, we test the robustness of the results from Figs. 11-12. The analysis is repeated 3 times, either changing the maximum ice cover from $70 \%$ to $50 \%$, the minimum required snowfall from 10 to $14 \mathrm{~cm}$, or the minimum difference between local, near-lake snowfall and nonlocal, continental snowfall from 4 to $6 \mathrm{~cm}$. For these three robustness tests, the resulting spatial map of heavy lake-effect snowstorm frequency is correlated with the original map in Fig. 11, producing spatial correlations of $0.98,0.92$, and 0.99 , respectively $(N=1629$ land points in the GLB). Therefore, the spatial distribution of heavy lake-effect snowstorm frequency is largely independent of the specific threshold values applied in the definition. According to the robustness tests, the seasonal cycle of heavy lake-effect snowstorm frequency is modestly affected by the choice of static threshold values, primarily for storms downwind of Lakes Huron and Superior (Fig. 12). Of the three threshold values, the choice in minimum local snowfall

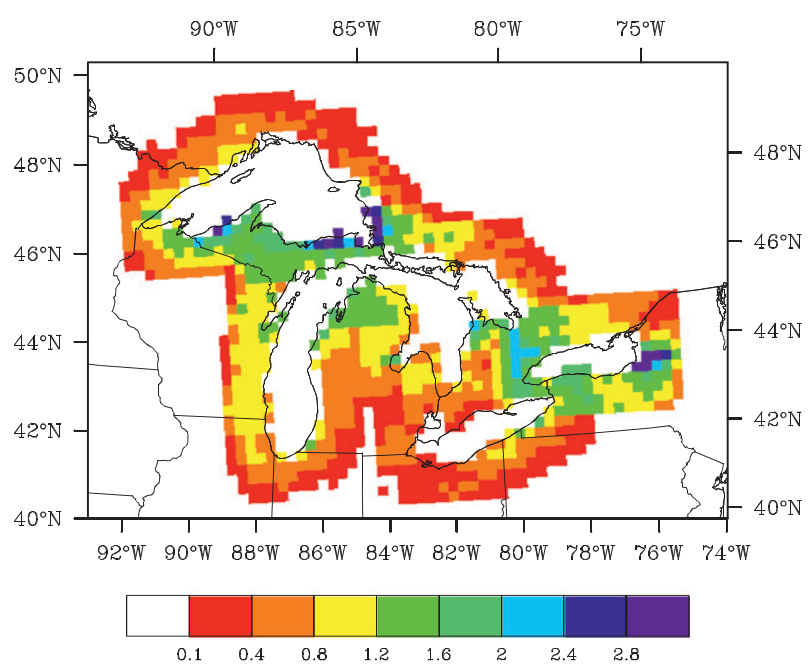

FIG. 11. Mean number of simulated heavy lake-effect snowfall days per year during 1976-2002. 

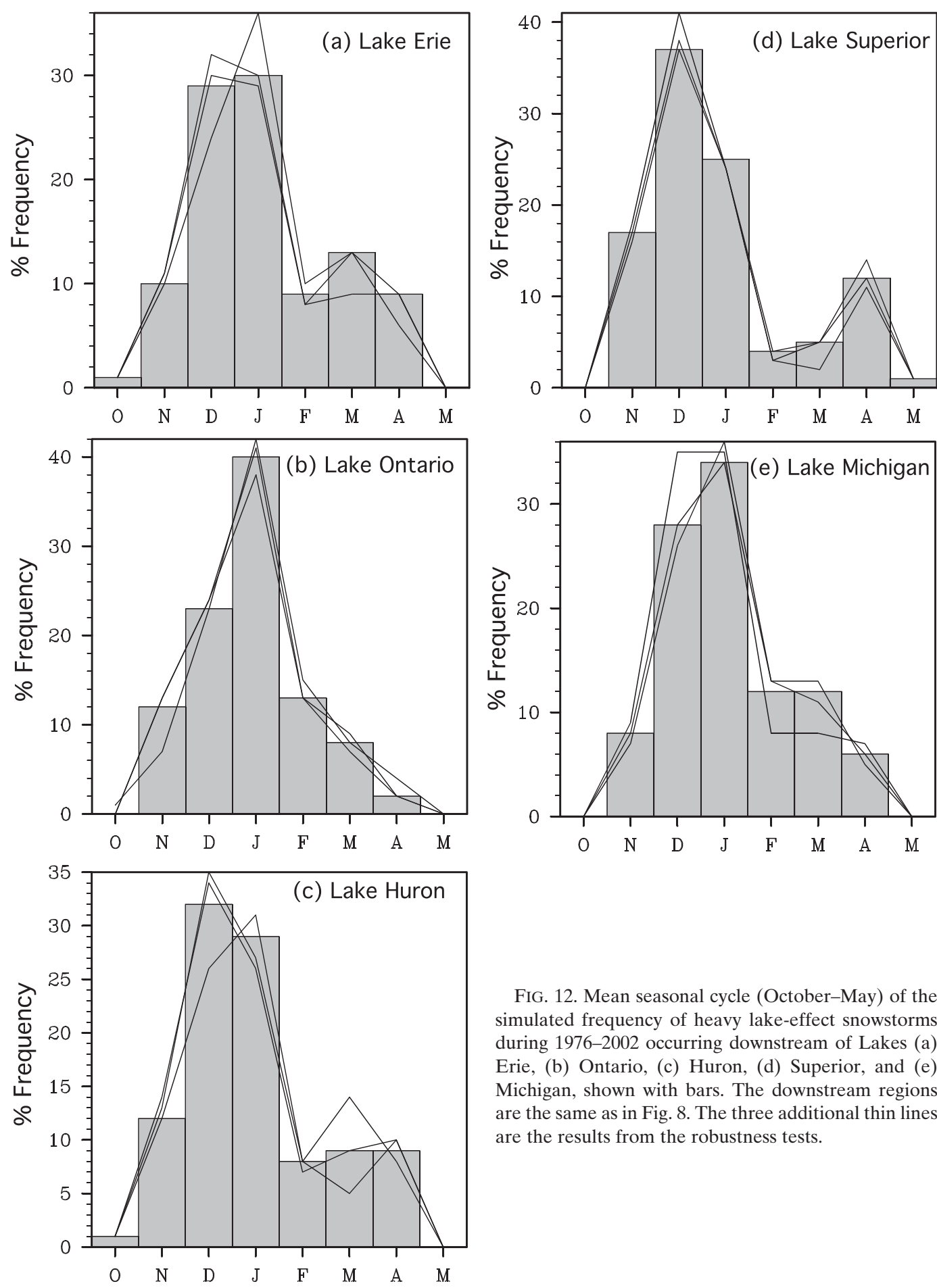

FIG. 12. Mean seasonal cycle (October-May) of the simulated frequency of heavy lake-effect snowstorms during 1976-2002 occurring downstream of Lakes (a) Erie, (b) Ontario, (c) Huron, (d) Superior, and (e) Michigan, shown with bars. The downstream regions are the same as in Fig. 8. The three additional thin lines are the results from the robustness tests.

has the most pronounced impact on the seasonal cycle of heavy lake-effect snowstorms. The use of static thresholds will allow for an easier application of this definition in future research, quantifying the projected twenty-first century change in heavy lake-effect snowstorm frequency.

The synoptic environment that favors the development of heavy lake-effect snowstorms is explored by compositing all identified heavy lake-effect snowstorm days for collocated weather stations at Sherman, New York $\left(42.15^{\circ} \mathrm{N}, 79.58^{\circ} \mathrm{W}\right)$; Baldwinsville, New York $\left(43.15^{\circ} \mathrm{N}\right.$, $\left.76.33^{\circ} \mathrm{W}\right)$; Owen Sound, Ontario, Canada $\left(44.58^{\circ} \mathrm{N}\right.$, 
(a) Sherman, NY (Lake Erie)

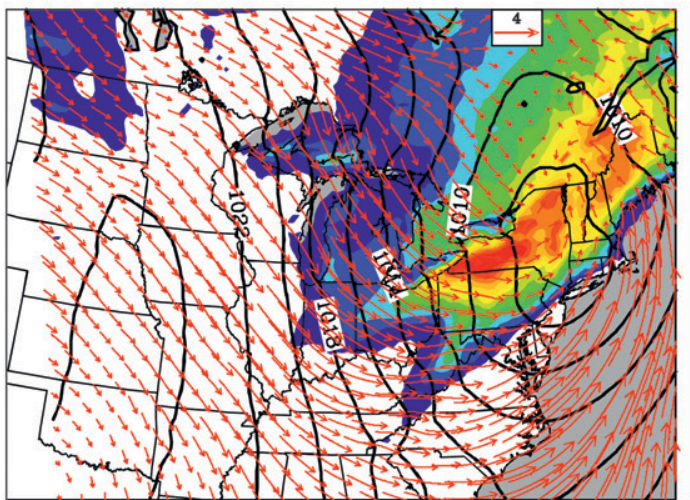

(b) Baldwinsville, NY (Lake Ontario)

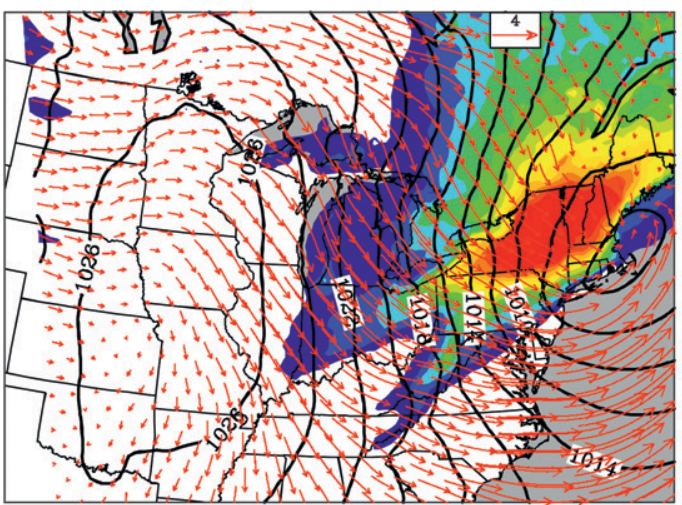

(c) Owen Sound, Ontario (Lake Huron)

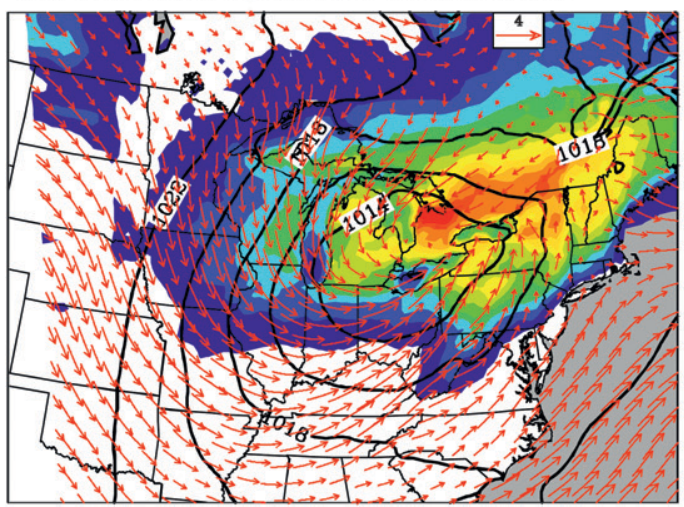

$\left.80.93^{\circ} \mathrm{W}\right)$; Marquette, Michigan $\left(46.52^{\circ} \mathrm{N}, 87.53^{\circ} \mathrm{W}\right)$; and Hesperia, Michigan $\left(43.58^{\circ} \mathrm{N}, 86.10^{\circ} \mathrm{W}\right)$. These cities are located downwind of Lakes Erie, Ontario, Huron, Superior, and Michigan, respectively (Fig. 13), and extensive daily snowfall observations are available for all five stations. The statistical significance of composited results is displayed in supplemental Figs. S2 and S3.

Based on the composite mean, heavy lake-effect snowstorms downwind of Lake Erie result from northwesterly low-level winds over the lake in response to a strong pressure gradient (about $18 \mathrm{hPa}$ ) between a $1025-\mathrm{hPa}$ (d) Marquette, MI (Lake Superior)

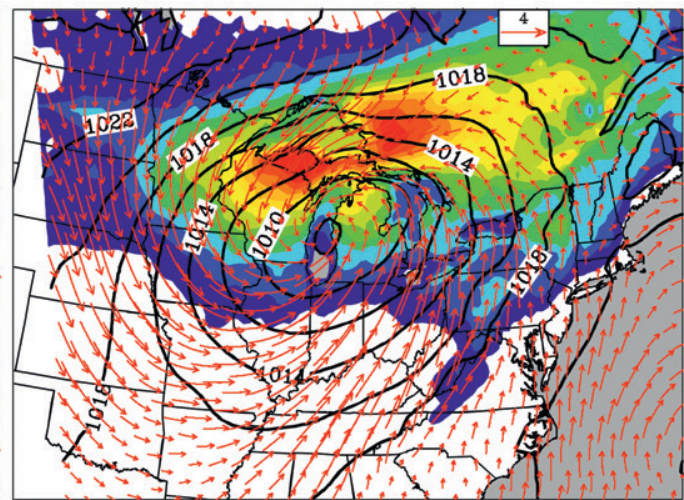

(e) Hesperia, MI (Lake Michigan)
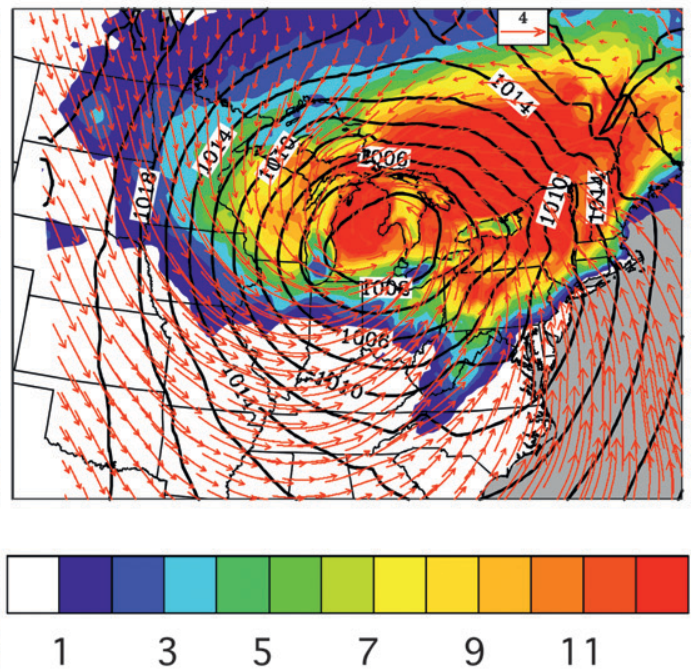

FIG. 13. Composite of simulated sea level pressure (contour, $\mathrm{hPa}$ ), 10-m wind vectors, and daily snowfall (cm) for days with heavy lake-effect snowstorms at (a) Sherman, NY; (b) Baldwinsville, NY; (c) Owen Sound, Ontario; (d) Marquette, MI; and (e) Hesperia, MI. These cities are located downstream of Lakes Erie, Ontario, Huron, Superior, and Michigan, respectively, as shown in Fig. 1. The total number of composited events is $28,43,49,47$, and 16 , respectively.

anticyclone centered around Kansas and a 1007-hPa cyclone over the Northeast (Fig. 13a). This anticyclone, positioned over North Dakota one day prior, is associated with a cold surge from Canada, advecting cold air over the Great Lakes and triggering lake-effect snowfall, particularly to the east of Lake Erie but also Lake Ontario. An examination of the 28 individual members of the composite indicates that an anticyclone is typically positioned over the central United States or southern Manitoba, Canada, while a cyclone or pressure trough is common in the northeastern United States or southern Quebec. 
There is a preferred surface air temperature that favors heavy lake-effect snowfall, which is cold enough to permit frozen precipitation but mild enough to hold sufficient moisture. Kunkel et al. (2002) determined that range to be from $-10^{\circ}$ to $0^{\circ} \mathrm{C}$. For the 28 simulated heavy lake-effect snowstorm days at Sherman, $71 \%$ of the cases fit within that range, with the most preferred temperatures just below freezing, between $-2^{\circ}$ and $0^{\circ} \mathrm{C}$.

According to the composite mean, heavy lake-effect snowstorms downwind of Lake Ontario result from a similar synoptic pattern as Lake Erie, except the anticyclone center is farther to the northeast over Iowa and the cyclone center is farther to the east, off the Massachusetts coast (Fig. 13b). The mean pressure gradient is $23 \mathrm{hPa}$, supporting strong northwesterlies over Lake Ontario. The simulated composites for Lakes Ontario and Erie are largely consistent with the composites of observed lake-effect snow events under strong westnorthwest flow, as produced by Ellis and Leathers (1996), which are characterized by a strong pressure gradient of $18 \mathrm{hPa}$ between a departing cyclone over the Canadian Maritime and an anticyclone building from the west. Of the five Great Lakes, simulated heavy lake-effect snowstorms downwind of Lakes Erie and Ontario are triggered by cold surges out of Canada and are associated with the coldest air masses, on average from $-8^{\circ}$ to $-18^{\circ} \mathrm{C}$ at $850 \mathrm{hPa}$ across the GLB (Fig. 14); in contrast, these snowstorms for the western lakes, Superior and Michigan, are typically associated with milder temperatures from $-1^{\circ}$ to $-13^{\circ} \mathrm{C}$.

Heavy lake-effect snowstorms occurring downwind of Lakes Huron, Superior, and Michigan are instead generally triggered by a cyclone in the GLB and strong cold-air advection behind its associated cold front (Figs. 13c-e). Across the domain, the cyclone, on average, is characterized by a horizontal pressure difference of about $16 \mathrm{hPa}$ for Lakes Superior and Michigan events but only $9 \mathrm{hPa}$ for Lake Huron events. This cyclone is typically located over Kansas, Arkansas, and Missouri on the previous day, suggesting a southwestnortheast "Colorado storm track." For all three lakes, the lake-effect snow is initiated following a cold frontal passage over the associated lake, as moderately cold air is advected down from Canada on the backside of the cyclone. The surface cyclone is typically positioned over the state of Michigan or the lower Great Lakes, just downstream of the lake-effect region. For Lakes Michigan, Superior, and Huron snowstorms, the mean cyclone deepens by 10,6 , and $4 \mathrm{hPa}$, respectively, as it enters the basin in response to the mild lakes.

The simulated lake-effect snowstorms are largely driven by atmospheric instability, as a cold air mass passes over an open, relatively warm lake, resulting in large lapse rates and fluxes of sensible and latent heat. As key terms in the quasigeostrophic omega equation, horizontal temperature advection and relative vorticity advection are important drivers of large-scale ascending motion and might contribute lift in these lakeeffect snowstorms (Figs. 14-15). However, they are not the most critical forcings for lake-effect snowstorms. In particular, positive vorticity advection at $500 \mathrm{hPa}$, to the east of the midtropospheric trough axis over the Midwest, destabilizes the lower to midtroposphere and reinforces the lifting mechanism for lake-effect snowstorms downwind of Lakes Superior and Huron (Figs. 15c,d).

To verify the robustness of these composites, a second set of composites is made for another city downstream of each lake, namely Fredonia, New York; Wolcott, New York; Midland, Ontario; Kenton, Michigan; and Traverse City, Michigan, for Lakes Erie, Ontario, Huron, Superior, and Michigan, respectively (within 43-168 km of their corresponding city from the first set). These composites of sea level pressure, wind, and snowfall are consistent with the original set of composites, verifying their robustness. For comparison against observations, for all five cities, composites are produced using the simulated heavy lake-effect snowstorm days for sea level pressure and 10-m wind from NARR and snowfall from station observations (Fig. 16). In each composite, RegCM4 accurately reproduces the spatial pattern of sea level pressure and surface streamlines, while capturing the snowfall pattern, including its peak downwind of the associated lake; however, for Lake Michigan storms, the surface cyclone is too deep in the model.

Further analysis is performed to verify the observed synoptic environment that produces heavy lake-effect snowfall. For Sherman, Baldwinsville, Owen Sound, Marquette, and Hesperia, the mean sea level pressure and $10-\mathrm{m}$ wind from NARR are composited (see supplemental Fig. S4) for the 20 days with heaviest observed snowfall in which archived NOAA weather maps confirm an off-lake wind flow. The observed synoptic pattern generally agrees with those simulated in Fig. 13, although the observed circulation is better described as a trough axis across the lakes in the Owen Sound cases (Lake Huron) than a weak, closed low as in the model. The model generally succeeds in capturing these observed lake-effect snow events, with $87 \%$ of the events displaying greater daily simulated snowfall than the model climatology for November-April, on average 4.9 times the climatological daily snowfall. The model generally struggles the most with simulating lake-effect snowstorms downwind of Lake Ontario. 
(a) Sherman, NY (Lake Erie)

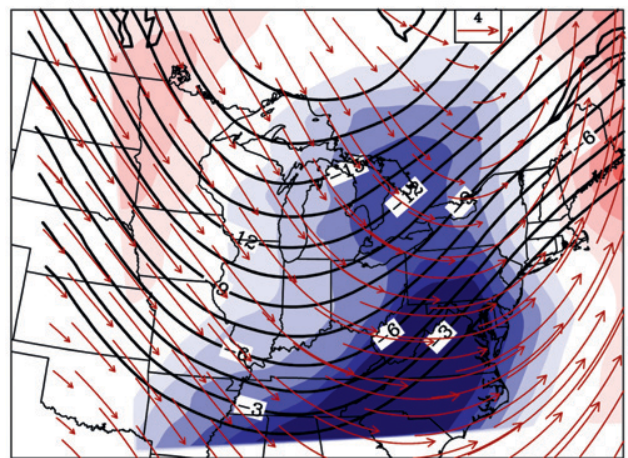

(b) Baldwinsville, NY (Lake Ontario)

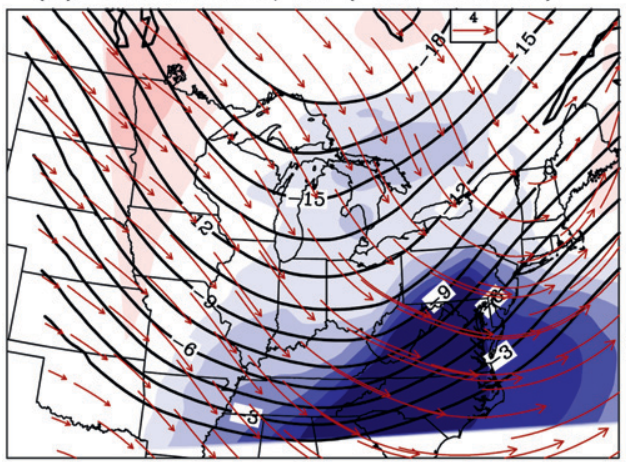

(c) Owen Sound, Ontario (Lake Huron)

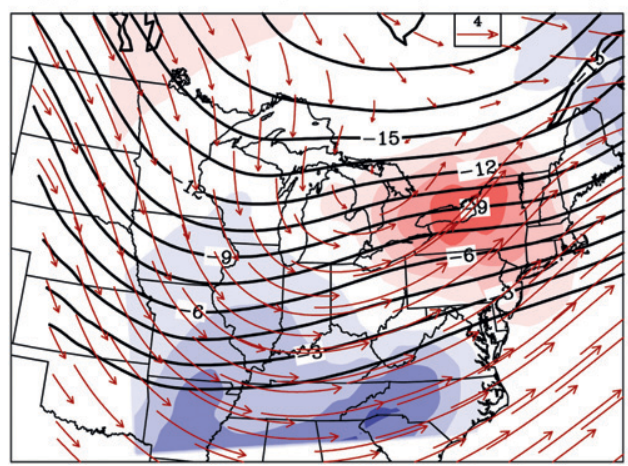

(d) Marquette, MI (Lake Superior)

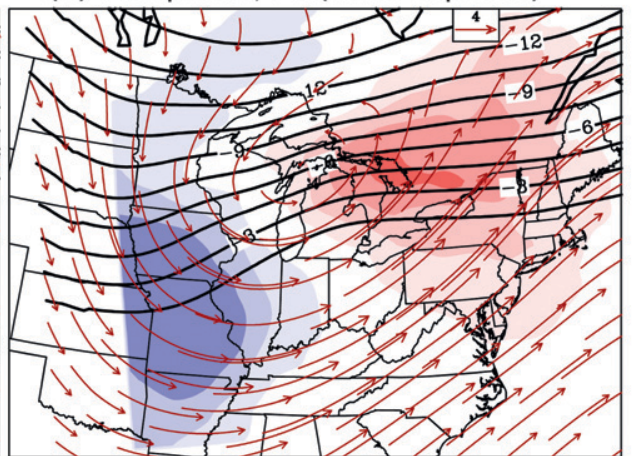

(e) Hesperia, MI (Lake Michigan)
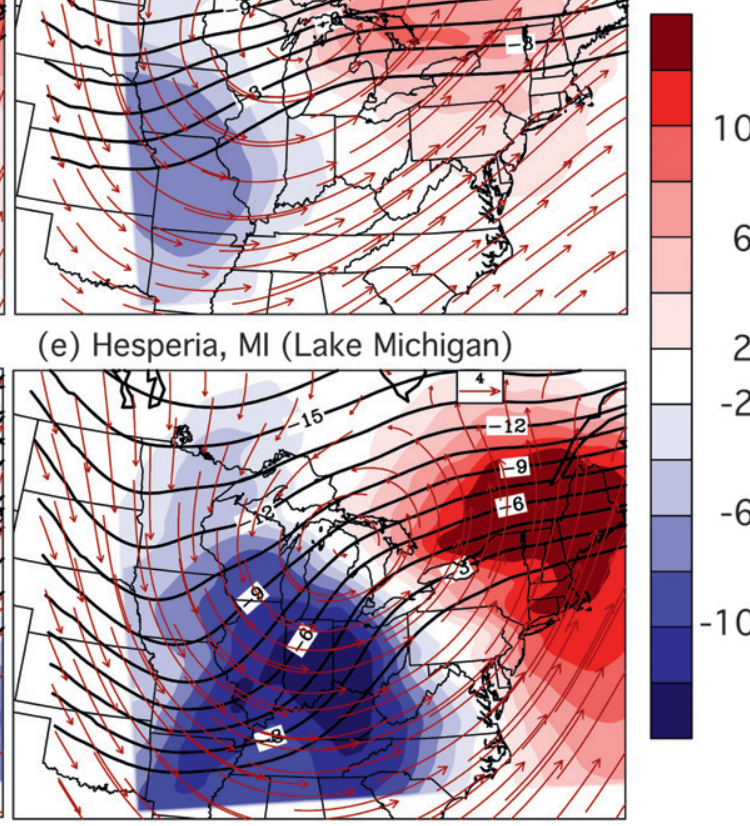

10

6

2

$-2$

$-6$

$-10$

FIG. 14. Composite of simulated 850-hPa temperature (contour, ${ }^{\circ} \mathrm{C}$ ), wind vectors, and horizontal temperature advection (shading, ${ }^{\circ} \mathrm{Cs}^{-1}, \times 10^{5}$ ) for days with heavy lake-effect snowstorms at (a) Sherman, NY; (b) Baldwinsville, NY; (c) Owen Sound, Ontario; (d) Marquette, MI; and (e) Hesperia, MI.

\section{Discussion and conclusions}

A 27-yr historical simulation is produced using ICTP RegCM4 with $25-\mathrm{km}$ grid spacing, with a domain centered on the Great Lakes Basin. Spatial and temporal patterns of lake ice cover and lake-effect snowfall are validated against observations, a definition for identifying heavy lake-effect snowstorms in RCM output is introduced, and the synoptic environment that produces these events is examined for each Great Lake.

RegCM4, coupled to a one-dimensional lake model (Hostetler and Bartlein 1990), reproduces the broad features of lake ice in terms of spatial distribution, seasonal cycle, and interannual variability. The lake

model is rather rudimentary since it neglects horizontal heat advection within the lakes and ice movement, resulting in a prolonged ice season with excessive ice cover. Martynov et al. (2010) encouraged the future incorporation of complex deep-lake processes and features, including seiches, water heating and convection below ice cover, and horizontal heat and ice movement. As noted by Martynov et al. (2012), one-dimensional lake models often struggle with deep lakes due to the absence of three-dimensional processes, including upwelling/downwelling, mixing induced by horizontal currents, and thermal bar formation. Future research should explore the benefits of coupling RegCM4 to a regional ocean model, which can generate a three-dimensional 
(a) Sherman, NY (Lake Erie)

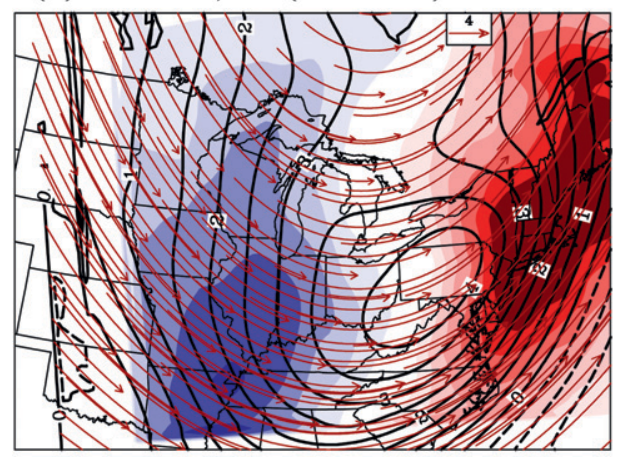

(b) Baldwinsville, NY (Lake Ontario)

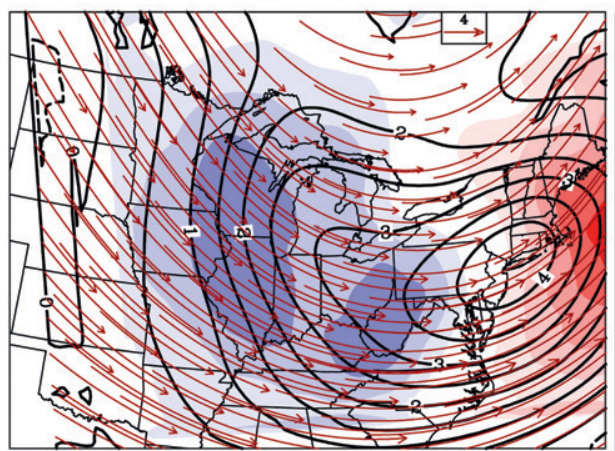

(c) Owen Sound, Ontario (Lake Huron)

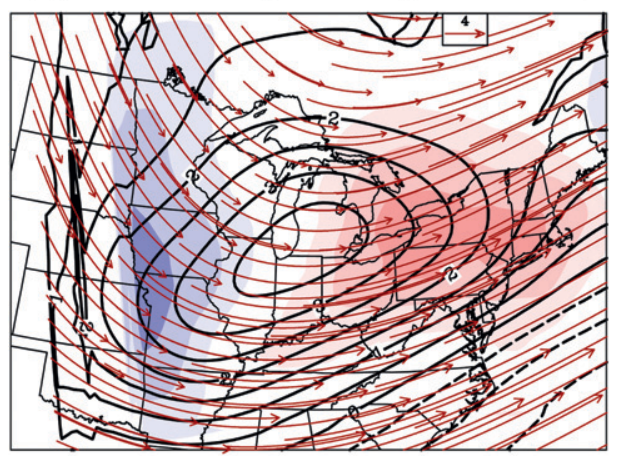

(d) Marquette, Ml (Lake Superior)

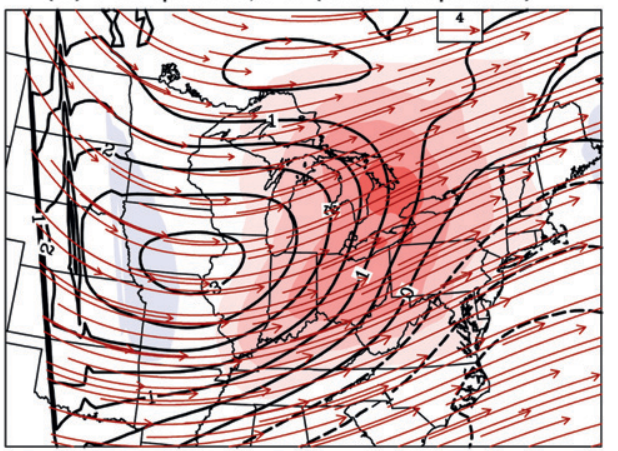

(e) Hesperia, MI (Lake Michigan)

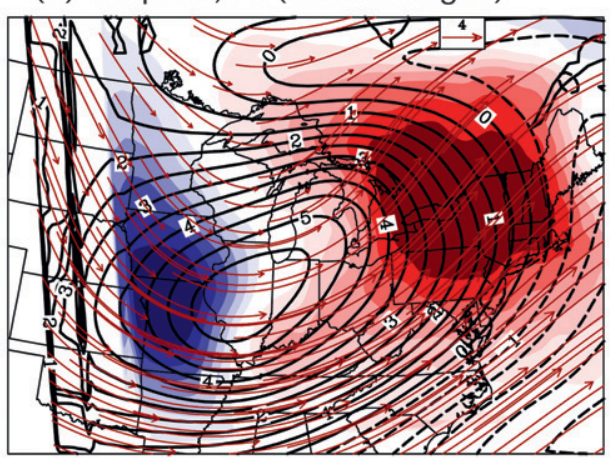

7.5

4.5

1.5

$-1.5$

$-4.5$

$-7.5$

FIG. 15. Composite of simulated 500-hPa relative vorticity (contour, $\mathrm{s}^{-1}, \times 10^{5}$ ), wind vectors, and horizontal relative vorticity (shading, $\mathrm{s}^{-2}, \times 10^{10}$ ) for days with heavy lake-effect snowstorms at (a) Sherman, NY; (b) Baldwinsville, NY; (c) Owen Sound, Ontario; (d) Marquette, MI; and (e) Hesperia, MI.

lake circulation and ice movement for the Great Lakes but at a large computation expense.

RegCM4 captures the broad climatological patterns of snowfall across the GLB, including the location of lake-effect snowfall peaks and the seasonal cycle and interannual variability of snowfall in those preferred regions. This study represents the first evaluation of simulated lake-effect snowfall in an RCM, assessed on a climate time scale rather than just case studies. At $25-\mathrm{km}$ grid spacing, the meso- $\beta$ features of lake-effect snowstorms are reproduced by the model. The eventual development of a nonhydrostatic version of $\mathrm{RegCM}$ will permit analysis of fine snowbands at resolutions of a few kilometers. Further testing is needed to investigate the impact of the vertical resolution on simulated boundary layer processes, including the formation of lake-effect snowbands, or potential benefits from applying newer reanalysis products, such as the NCEP Climate Forecast System (CFS; Saha et al. 2010).

A definition is introduced for identifying heavy lakeeffect snowstorms as simulated by an RCM, using criteria based on location, wind direction, lake ice cover, and snowfall (both near lake and continental). While this lake-effect snowstorm definition is founded in fundamental concepts of synoptic meteorology, its application to regional climate modeling is novel. Heavy lake-effect snowstorms are simulated most abundantly downwind of the Great Lakes, especially to the east of 
(a) Sherman, NY (Lake Erie)

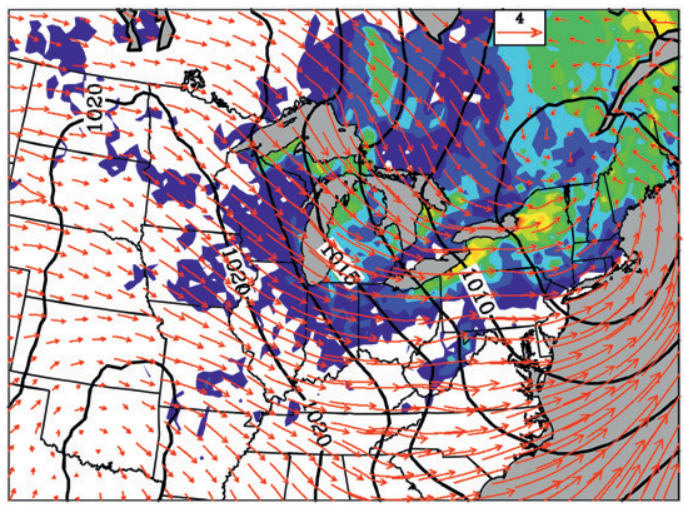

(b) Baldwinsville, NY (Lake Ontario)

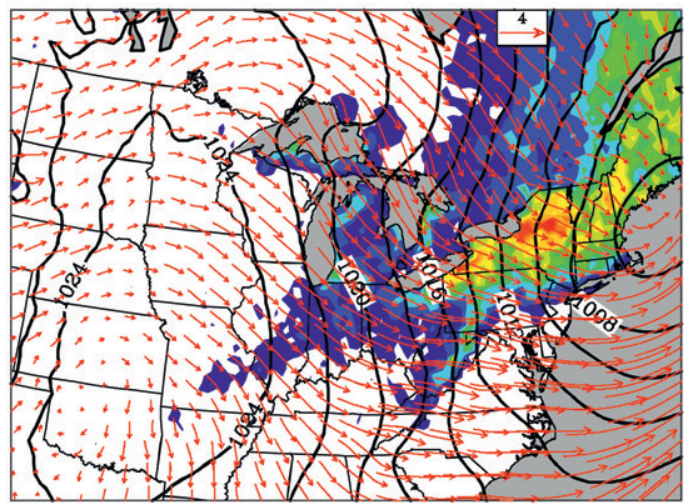

(c) Owen Sound, Ontario (Lake Huron)

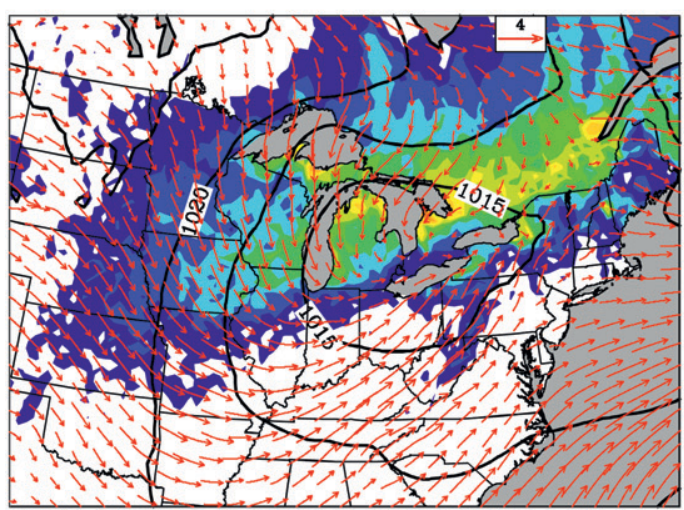

Lake Ontario and to the east and south of Lake Superior. Rather than from quasigeostrophic forcing from positive temperature advection or vorticity advection, these storms are triggered by large turbulent fluxes off the lakes and associated atmospheric instability, as cold, dry continental air from Canada passes over the lakes. Simulated heavy lake-effect snowstorms occur most frequently in December-January, prior to the extensive ice cover in February. Case study composites reveal that the synoptic environment for lake-effect storms downwind of Lakes Ontario and Erie is unique from that of (d) Marquette, MI (Lake Superior)

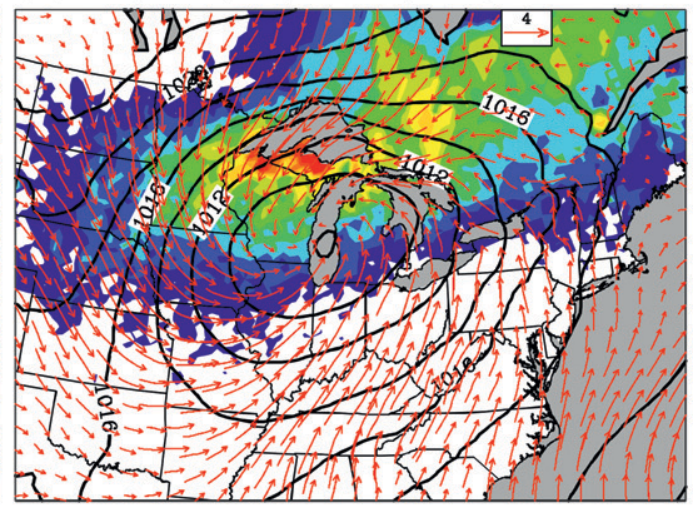

(e) Hesperia, MI (Lake Michigan)
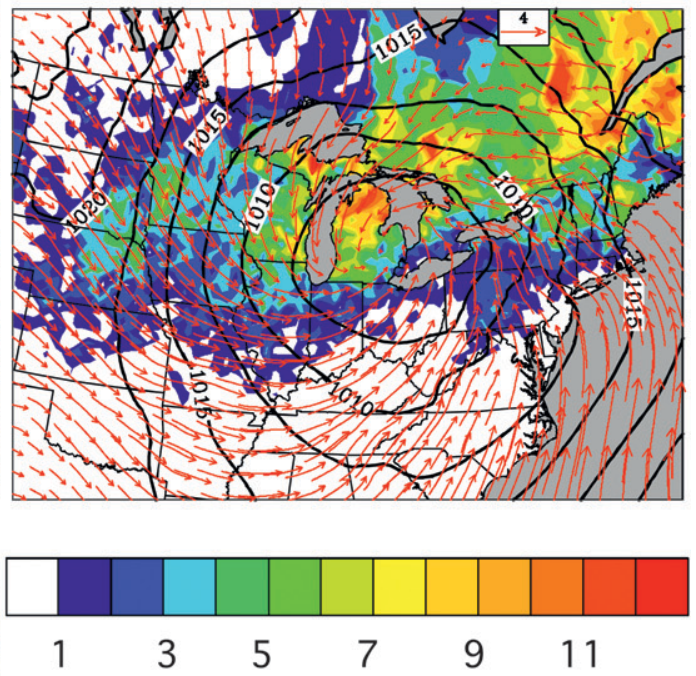

FIG. 16. Composite of the same heavy lake-effect snowstorm days in Fig. 13 but shown with sea level pressure and 10-m wind from the North American Regional Reanalysis and observed snowfall from station observations (National Climatic Data Center and Environment Canada).

the other three lakes. Heavy lake-effect snowstorms are generally produced downwind of Lakes Ontario and Erie in response to an extreme Canadian cold surge associated with a central United States' anticyclone, while a cyclone is positioned over the northeastern United States or just off its coast. These simulated features are consistent with observational studies by Niziol (1987), Ellis and Leathers (1996), and Ballentine et al. (1998). Simulated heavy lake-effect snowstorms downwind of the westernmost lakes, Superior, Michigan, and Huron, generally result from a cyclone traveling from 
the south-central United States into the GLB with a cold front passing over the associated lake. Liu and Moore (2004) found a similar synoptic pattern in the observations associated with lake-effect snowfall over southern Ontario to the east of Lake Huron. Further research will apply RegCM4 for future scenarios to assess climate change's impact on the frequency of heavy lake-effect snowstorms, applying the definition introduced here.

Acknowledgments. This study was funded by grants from NOAA/Climate Change Data and Detection and the University of Wisconsin-Madison's Climate, People, and Environment Program, along with a EPA-funded contract from the Michigan Department of Natural Resources. The authors are thankful for assistance from ICTP, particularly Drs. Graziano Guiliani, Nellie Elguindi, and Filippo Giorgi, in debugging and improving the RegCM4 model. The authors appreciate insightful discussions with Ms. Kathleen Holman and the helpful comments from three reviewers. Computational resources were provided through the Teragrid from the University of Texas at Austin and the University of Illinois at Urbana-Champaign.

\section{REFERENCES}

Anderson, E. A., 1976: A point energy and mass balance model of a snow cover. NOAA Tech. Rep. NWS 19, 150 pp.

- 2006: Snow accumulation and ablation model-SNOW 17. U.S. National Weather Service, Silver Spring, MD, 61 pp.

Anthes, R. A., 1977: A cumulus parameterization scheme utilizing a one-dimensional cloud model. Mon. Wea. Rev., 105, 270-286.

Assel, R. A., 1990: An ice-cover climatology for Lake Erie and Lake Superior for the winter seasons 1897-98 to 1982-83. Int. J. Climatol., 10, 731-748.

- 1999: Great Lakes ice cover. Potential Climate Change Effects on Great Lakes Hydrodynamics and Water Quality, D. C. L. Lam and W. M. Schertzer, Eds., American Society of Civil Engineers, 1-21.

- 2003: Great Lakes ice cover, first ice, last ice, and ice duration: Winters 1973-2002. NOAA Tech. Memo. GLERL-125, 49 pp.

_- 2005: Classification of annual Great Lakes ice cycles: Winters of 1973-2002. J. Climate, 18, 4895-4905.

—, D. C. Norton, and K. C. Cronk, 2002: A Great Lakes ice cover digital data set for winters 1973-2000. NOAA Tech. Memo. GLERL-121, Great Lakes Environmental Research Laboratory, Ann Arbor, MI, 46 pp.

Ballentine, R. J., 1982: Numerical simulation of land-breezeinduced snowbands along the western shore of Lake Michigan. Mon. Wea. Rev., 110, 1544-1553.

—, E. C. Chermack, A. Stamm, D. Frank, M. Thomas, and G. Beck, 1992: Preliminary numerical simulations of the 31 January 1991 lake-effect snowstorm. Proc. 49th Annual Eastern Snow Conf., Oswego, NY, CRREL, 115-123. [Available from U.S. Army, CRREL, 72 Lyme Rd., Hanover, NH 03755.$]$

—, A. J. Stamm, E. F. Chermack, G. P. Byrd, and D. Schleede, 1998: Mescoscale model simulation of the 4-5 January 1995 lake-effect snowstorm. Wea. Forecasting, 13, 893-920.
Bates, G. T., F. Giorgi, and S. W. Hostetler, 1993: Toward the simulation of the effects of the Great Lakes on regional climate. Mon. Wea. Rev., 121, 1373-1387.

_, S. W. Hostetler, and F. Giorgi, 1995: Two-year simulation of the Great Lakes region with a coupled modeling system. Mon. Wea. Rev., 123, 1505-1522.

Braham, R. R., Jr., and M. J. Dungey, 1984: Quantitative estimates of the effect of Lake Michigan on snowfall. J. Climate Appl. Meteor., 23, 940-949.

Brown, L. C., and C. R. Duguay, 2010: The response and role of ice cover in lake-climate interactions. Prog. Phys. Geogr., 34, 671704, doi:10.1177/0309133310375653.

Burnett, A. W., M. E. Kirby, H. T. Mullins, and W. P. Patterson, 2003: Increasing Great Lake-effect snowfall during the twentieth century: A regional response to global warming? J. Climate, 16, 3535-3542.

Byrd, G. P., R. A. Anstett, J. E. Heim, and D. M. Usinski, 1991: Mobile sounding observations of lake-effect snowbands in western and central New York. Mon. Wea. Rev., 119, 2323-2332.

Chagnon, S. A., Jr., 1979: How a severe winter impacts on individuals. Bull. Amer. Meteor. Soc., 60, 110-114.

Cohen, S. J., and T. R. Allsopp, 1988: The potential impacts of a scenario of $\mathrm{CO}_{2}$-induced climatic change on Ontario, Canada. J. Climate, 1, 669-681.

Cordeira, J. M., and N. F. Laird, 2008: The influence of ice cover on two lake-effect snow events over Lake Erie. Mon. Wea. Rev., 136, 2747-2763.

Dewey, K. F., 1979: An objective forecast method developed for Lake Ontario induced snowfall systems. J. Appl. Meteor., 18, 787-793.

Dickinson, R. E., P. J. Kennedy, A. Henderson-Sellers, and M. Wilson, 1986: Biosphere-Atmosphere Transfer Scheme (BATS) for the NCAR Community Climate Model. National Center for Atmospheric Research Tech. Note NCAR/TN275+STR, 69 pp.

— A. Henderson-Sellers, and P. J. Kennedy, 1993: BiosphereAtmosphere Transfer Scheme (BATS) version 1e as coupled to the NCAR Community Climate Model. National Center for Atmospheric Research Tech. Note NCAR/TN-387+STR, $72 \mathrm{pp}$.

Eichenlaub, V. L., 1970: Lake effect snowfall to the lee of the Great Lakes: Its role in Michigan. Bull. Amer. Meteor. Soc., 51, 403412.

_ 1979: Weather and Climate of the Great Lakes Region. University of Notre Dame Press, $335 \mathrm{pp}$.

Elguindi, N., and Coauthors, 2011: Regional climatic model RegCM user manual version 4.1. Abdus Salam International Centre for Theoretical Physics, $32 \mathrm{pp}$.

Ellenton, G. E., and M. B. Danard, 1979: Inclusion of sensible heating in convective parameterization applied to lake-effect snow. Mon. Wea. Rev., 107, 551-565.

Ellis, A. W., and D. J. Leathers, 1996: A synoptic climatological approach to the analysis of lake-effect snowfall: Potential forecasting applications. Wea. Forecasting, 11, 216-229.

Fritsch, J. M., and C. F. Chappell, 1980: Numerical prediction of convectively driven mesoscale pressure systems. Part I: Convective parameterization. J. Atmos. Sci., 37, 1722-1733.

Gerbush, M. R., D. A. R. Kristovich, and N. F. Laird, 2008: Mesoscale boundary layer and heat fluxes variations over pack ice-covered Lake Erie. J. Appl. Meteor. Climatol., 47, 668-682.

Giorgi, F., and Coauthors, 2012: RegCM4: Model description and preliminary tests over multiple CORDEX domains. Climate Res., 52, 7-29. 
Grell, G. A., 1993: Prognostic evaluation of assumptions used by cumulus parameterizations. Mon. Wea. Rev., 121, 764-787.

— J J. Dudhia, and D. R. Stauffer, 1994: Description of the fifth generation Penn State/NCAR Mesoscale Model (MM5). NCAR Tech. Rep. TN-398+STR, Boulder, CO, 121 pp.

Guildford, S. J., L. L. Hendzel, H. J. Kling, E. J. Fee, G. G. C. Robinson, R. E. Hecky, and S. E. M. Kasian, 1994: Effects of lake size on phytoplankton nutrient status. Can. J. Fish. Aquat. Sci., 51, 2769-2783.

Hakanson, L., 1995: Models to predict secchi depth in small glacial lakes. Aquat. Sci., 57, 31-53.

Hill, J. D., 1971: Snow squalls in the lee of Lakes Erie and Ontario. NOAA Tech. Memo. NWS ER-43, 20 pp. [NTIS COM-7200959.]

Hjelmfelt, M. R., 1990: Numerical study of the influence of environmental conditions on lake-effect snowstorms over Lake Michigan. Mon. Wea. Rev., 118, 138-150.

— airflow over Lake Michigan for a major lake-effect snow event. Mon. Wea. Rev., 111, 205-219.

Holman, K. D., A. D. Gronewold, M. Notaro, and A. Zarrin, 2012: Improving historical precipitation estimates around the Lake Superior watershed. Geophys. Res. Lett., 39, L03405, doi:10.1029/2011GL050468.

Holroyd, E. W., III, 1971: Lake-effect cloud bands as seen from satellites. J. Atmos. Sci., 28, 1165-1170.

Holtslag, A. A. M., E. I. F. de Bruijn, and H.-L. Pan, 1990: A high resolution air mass transformation model for short-range weather forecasting. Mon. Wea. Rev., 118, 1561-1575.

Hostetler, S. W., 1991: Simulation of lake ice and its effect on the late-Pleistocene evaporation rate of Lake Lahontan. Climate Dyn., 6, 43-48.

— application to modeling lake-level variations at Harney-Malheur Lake, Oregon. Water Resour. Res., 26, 2603-2612.

— - G. T. Bates, and F. Giorgi, 1993: Interactive coupling of a lake thermal model with a regional climate model. J. Geophys. Res., 98 (D3), 5045-5057.

Kalnay, E., and Coauthors, 1996: The NCEP/NCAR 40-Year Reanalysis Project. Bull. Amer. Meteor. Soc., 77, 437-471.

Kiehl, J. T., J. J. Hack, G. B. Bonan, B. A. Boville, B. P. Breigleb, D. Williamson, and P. Rasch, 1996: Description of NCAR Community Climate Model (CCM3). National Center for Atmospheric Research Tech. Rep. NCAR/TN-420+STR, 152 pp.

Kocin, P. J., and L. W. Uccellini, 2004: A snowfall impact scale derived from Northeast storm snowfall distributions. Bull. Amer. Meteor. Soc., 85, 177-194.

Kristovich, D. A. R., and N. F. Laird, 1998: Observations of widespread lake-effect cloudiness: Influences of lake surface temperature and upwind conditions. Wea. Forecasting, 13, 811-821.

Kunkel, K. E., N. E. Westcott, and D. A. R. Kristovich, 2002: Assessment of potential effects of climate change on heavy lakeeffect snowstorms near Lake Erie. J. Great Lakes Res., 28, 521-536.

—, M. A. Palecki, K. G. Hubbard, D. A. Robinson, K. T. Redmond, and D. R. Easterling, 2007: Trend identification in twentieth-century U.S. snowfall: The challenges. J. Atmos. Oceanic Technol., 24, 64-73.

, L. Ensor, M. Palecki, D. Easterling, D. Robinson, K. G. Hubbard, and K. Redmond, 2009: A new look at lake-effect snowfall trends in the Laurentian Great Lakes using a temporally homogeneous data set. J. Great Lakes Res., 35, 23-29.
Laird, N. F., 1999: Observation of coexisting mesoscale lake-effect vortices over the western Great Lakes. Mon. Wea. Rev., 127, 1137-1141.

— , and D. A. R. Kristovich, 2004: Comparison of observations with idealized model results for a method to resolve winter lakeeffect mesoscale morphology. Mon. Wea. Rev., 132, 1093-1103.

Lavoie, R. L., 1972: A mesoscale numerical model of lake-effect storms. J. Atmos. Sci., 29, 1025-1040.

Leathers, D. J., and A. W. Ellis, 1993: Relationships between synoptic weather type frequencies and snowfall trends in the lee of Lakes Erie and Ontario. Proc. 61st Annual Western Snow Conf., Quebec City, QC, Canada, CRREL, 325-330.

Liu, A. Q., and G. W. K. Moore, 2004: Lake-effect snowstorms over southern Ontario, Canada, and their associated synoptic-scale environment. Mon. Wea. Rev., 132, 2595-2609.

Maesaka, T., G. W. K. Moore, Q. Liu, and K. Tsuboki, 2006: A simulation of a lake effect snowstorm with a cloud resolving numerical model. Geophys. Res. Lett., 33, L20813, doi:10.1029/ 2006GL026638.

Mahoney, E. A., and T. A. Niziol, 1997: BUFKIT: A software application tool kit for predicting lake-effect snow. Preprints, 13th Int. Conf. on Interactive Information and Processing Systems for Meteorology, Oceanography, and Hydrology, Long Beach, CA, Amer. Meteor. Soc., 388-391.

Martynov, A., K. Sushama, and R. Laprise, 2010: Simulation of temperate freezing lakes by one-dimensional lake models: Performance assessment for interactive coupling with regional climate models. Boreal Environ. Res., 15, 143-164.

—, L. Sushama, R. Laprise, K. Winger, and B. Dugas, 2012: Interactive lakes in the Canadian Regional Climate Model, version 5: The role of lakes in the regional climate of North America. Tellus, 64, 16226, doi:10.3402/tellusa.v64i0.16226.

Mesinger, F., and Coauthors, 2006: North American Regional Reanalysis. Bull. Amer. Meteor. Soc., 87, 343-360.

Miner, T. J., and J. M. Fritsch, 1997: Lake-effect rain events. Mon. Wea. Rev., 125, 3231-3248.

Niziol, T. A., 1987: Operational forecasting of lake effect snowfall in western and central New York. Wea. Forecasting, 2, 310-321.

_ W. R. Snyder, and J. S. Waldstreicher, 1995: Winter weather forecasting throughout the eastern United States. Part IV: Lake effect snow. Wea. Forecasting, 10, 61-77.

Norton, D. C., and S. J. Bolsenga, 1993: Spatiotemporal trends in lake effect and continental snowfall in the Laurentian Great Lakes, 1951-1980. J. Climate, 6, 1943-1955.

Notaro, M., K. Holman, A. Zarrin, E. Fluck, S. Vavrus, and V. Bennington, 2013: Influence of the Laurentian Great Lakes on regional climate. J. Climate, 26, 789-804.

Orlanski, I., 1975: A rational subdivision of scales for atmospheric processes. Bull. Amer. Meteor. Soc., 56, 527-530.

Pal, J. S., E. E. Small, and E. A. B. Eltahir, 2000: Simulation of regional-scale water and energy budgets: Representation of subgrid cloud and precipitation processes within RegCM. J. Geophys. Res., 105 (D24), 29579-29594.

— , and Coauthors, 2007: Regional climate modeling for the developing world: The ICTP RegCM3 and RegCNET. Bull. Amer. Meteor. Soc., 88, 1395-1409.

Passarelli, R. E., Jr., and R. R. Braham Jr., 1981: The role of the winter land breeze in the formation of Great Lake snow storms. Bull. Amer. Meteor. Soc., 62, 482-491.

Patterson, J. C., and P. F. Hamblin, 1988: Thermal simulation of a lake with winter ice cover. Limnol. Oceanogr., 33, 323-338.

Pease, S. R., W. A. Lyons, C. S. Keen, and M. R. Hjelmfelt, 1988: Mesoscale spiral vortex embedded within a Lake Michigan 
snow squall band: High resolution satellite observations and numerical model simulations. Mon. Wea. Rev., 116, 1374-1380.

Perroud, M., S. Goyette, A. Martynov, M. Beniston, and O. Anneville, 2009: Simulation of multiannual thermal profiles in deep Lake Geneva: A comparison of one-dimensional lake models. Limnol. Oceanogr., 54, 1574-1594.

Rayner, N. A., E. B. Horton, D. E. Parker, C. K. Folland, and R. B. Hackett, 1996: Version 2.2 of the Global Sea Ice and Sea Surface Temperature data set, 1903-1994. Climate Research Tech. Note CRTN74, Hadley Centre, Met Office, Bracknell, United Kingdom, 21 pp.

Reinking, R. F., and Coauthors, 1993: The Lake Ontario Winter Storms (LOWS) project. Bull. Amer. Meteor. Soc., 74, 18281849.

Roebber, P. J., S. L. Bruening, D. M. Schultz, and J. W. Cortinas Jr., 2003: Improving snowfall forecasting by diagnosing snow density. Wea. Forecasting, 18, 264-287.

Saha, S., and Coauthors, 2010: The NCEP Climate Forecast System Reanalysis. Bull. Amer. Meteor. Soc., 91, 1015-1057.

Scavia, D., G. L. Fahnenstiel, M. S. Evans, D. J. Jude, and J. T. Lehman, 1986: Influence of salmonine predation and weather on long-term water quality trends in Lake Michigan. Can. J. Fish. Aquat. Sci., 43, 435-443.

Schmidlin, T. W., 1993: Impacts on severe winter weather during December 1989 in the Lake Erie snowbelt. J. Climate, 6, 759767.

— J. Kosarik, D. J. Edgell, and M. A. Delaney, 1992: Design ground snow loads for Ohio. J. Appl. Meteor., 31, 622-627.

Sheridan, L. W., 1941: The influence of Lake Erie on local snows in Western New York. Bull. Amer. Meteor. Soc., 22, 393-395.

Shi, J. J., and Coauthors, 2010: WRF simulations of the 20-22 January 2007 snow events over eastern Canada: Comparison with in situ and satellite observations. J. Appl. Meteor. Climatol., 49, 2246-2266.
Sousounis, P. J., and J. M. Fritsch, 1994: Lake aggregate mesoscale disturbances. Part II: A case study of the effects on regional and synoptic-scale weather systems. Bull. Amer. Meteor. Soc., 75, 1793-1811.

Stepanenko, V. M., S. Goyette, A. Martynov, M. Perroud, X. Fang, and D. Mironov, 2010: First steps of a Lake Model Intercomparison Project: LakeMIP. Boreal Environ. Res., 15, 191-202.

Sterner, R. W., 2010: In situ-measured primary production in Lake Superior. J. Great Lakes Res., 36, 139-149.

Subin, Z. M., W. J. Riley, and D. Mironov, 2012: An improved lake model for climate simulations: Model structure, evaluation, and sensitivity analyses in CESM1. J. Adv. Model. Earth Syst., 4, M02001, doi:10.1029/2011MS000072.

Torma, C., E. Coppola, F. Giorgi, J. Bartoly, and R. Pongracz, 2011: Validation of a high resolution version of the regional climate model RegCM3 over the Carpathian basin. J. Hydrometeor., 12, 84-100.

Tripoli, G. J., 2005: Numerical study of the 10 January 1998 lakeeffect bands observed during Lake-ICE. J. Atmos. Sci., 62, 3232-3249.

Vavrus, S., M. Notaro, and A. Zarrin, 2013: The role of ice cover in heavy lake-effect snowstorms over the Great Lakes Basin as simulated by RegCM4. Mon. Wea. Rev., 141, 148-165.

Warner, T. T., and N. L. Seaman, 1990: A real-time, mesoscale numerical weather prediction system used for research, teaching, and public service at the Pennsylvania State University. Bull. Amer. Meteor. Soc., 71, 792-805.

Wiggin, B. L., 1950: Great snows of the Great Lakes. Weatherwise, 3, 123-126.

Willmott, C. J., and K. Matsuura, cited 2000: Terrestrial air temperature and precipitation: Monthly and annual time series (1950-1996) (Version 1.01). [Available online at http://climate. geog.udel.edu/ climate/html_pages/download.html.] 